\title{
Inoculation with Plant Growth-Promoting Bacteria to Reduce Phosphate Fertilization Requirement and Enhance Technological Quality and Yield of Sugarcane
}

\author{
Poliana Aparecida Leonel Rosa ${ }^{1}$, Fernando Shintate Galindo 2,*D, Carlos Eduardo da Silva Oliveira ${ }^{1}$, \\ Arshad Jalal ${ }^{1}$ (D), Emariane Satin Mortinho ${ }^{1}$, Guilherme Carlos Fernandes ${ }^{1}$, Evelyn Maria Rocha Marega ${ }^{1}$, \\ Salatiér Buzetti ${ }^{1}$ and Marcelo Carvalho Minhoto Teixeira Filho ${ }^{1}$ (D)
}

check for updates

Citation: Rosa, P.A.L.; Galindo, F.S.; Oliveira, C.E.d.S.; Jalal, A.; Mortinho, E.S.; Fernandes, G.C.; Marega, E.M.R.; Buzetti, S.; Teixeira Filho, M.C.M. Inoculation with Plant GrowthPromoting Bacteria to Reduce Phosphate Fertilization Requirement and Enhance Technological Quality and Yield of Sugarcane. Microorganisms 2022, 10 , 192. https://doi.org/10.3390/ microorganisms 10010192 Academic Editor: Diana Di Gioia

Received: 16 December 2021 Accepted: 11 January 2022

Published: 17 January 2022

Publisher's Note: MDPI stays neutral with regard to jurisdictional claims in published maps and institutional affiliations.

Copyright: (C) 2022 by the authors. Licensee MDPI, Basel, Switzerland. This article is an open access article distributed under the terms and conditions of the Creative Commons Attribution (CC BY) license (https:// creativecommons.org/licenses/by/ $4.0 /)$.
1 Department of Plant Health, Rural Engineering, and Soils, São Paulo State University, Ilha Solteira 15345-000, Brazil; polianaleonelrosa@gmail.com (P.A.L.R.); ces.oliveira@unesp.br (C.E.d.S.O.); arshad.jalal@unesp.br (A.J.); emariane.satin@unesp.br (E.S.M.); guilherme.carlos.fernandes@gmail.com (G.C.F.); evelynmarega8@gmail.com (E.M.R.M.); sbuzetti@agr.feis.unesp.br (S.B.); mcmtf@yahoo.com.br (M.C.M.T.F.)

2 Center for Nuclear Energy in Agriculture, University of São Paulo, Piracicaba 13416-000, Brazil

* Correspondence: fsgalindo@usp.br; Tel.: +55-(18)98120-8054

\begin{abstract}
Phosphorus (P) is a critical nutrient for high sugarcane yields throughout its cultivation cycles, however, a higher amount of $\mathrm{P}$ becomes rapidly unavailable to plants due to its adsorption to soil colloids. Some plant growth-promoting bacteria (PGPBs) may be able to enhance P availability to plants and produce phytohormones that contribute to crop development, quality, and yield. Thus, this study aimed to evaluate leaf concentrations of nitrogen $(\mathrm{N})$ and $\mathrm{P}$, yield, and technological quality of sugarcane as a function of different levels of phosphate fertilization associated with inoculation of PGPBs. The experiment was carried out at Ilha Solteira, São Paulo-Brazil. The experimental design was randomized blocks with three replications, consisting of five phosphorus rates $(0,25$, 50,75 , and $100 \%$ of the recommended $\mathrm{P}_{2} \mathrm{O}_{5}$ rate) and eight inoculations, involving three species of PGPBs (Azospirillum brasilense, Bacillus subtilis, and Pseudomonas fluorescens) which were applied combined or in a single application into the planting furrow of RB92579 sugarcane variety. The inoculation of $B$. subtilis and $P$. fluorescens provided a higher concentration of leaf $\mathrm{P}$ in sugarcane. The $\mathrm{P}_{2} \mathrm{O}_{5}$ rates combined with inoculation of bacteria alter technological variables and stalk yield of sugarcane. The excess and lack of phosphate fertilizer is harmful to sugarcane cultivation, regardless of the use of growth-promoting bacteria. We recommend the inoculation with A. brasilense $+B$. subtilis associated with $45 \mathrm{~kg} \mathrm{ha}^{-1}$ of $\mathrm{P}_{2} \mathrm{O}_{5}$ aiming at greater stalk yield. This treatment also increases sugar yield, resulting in a savings of $75 \%$ of the recommended $\mathrm{P}_{2} \mathrm{O}_{5}$ rate, thus being a more efficient and sustainable alternative for reducing sugarcane crop production costs.
\end{abstract}

Keywords: phosphorus; inoculation; plant-cane; reduction of phosphate fertilization; plant growth promotion; Saccharum spp.

\section{Introduction}

Sugarcane (Saccharum officinarum L.) is one of the world's main agricultural crops, and its largest producing country is Brazil, which accounts for $34 \%$ of global production [1]. In the $2018 / 19$ crop season, national production reached 620.4 million tons, occupying an area of 8.6 million hectares with an average yield of $72.2 \mathrm{t} \mathrm{ha}^{-1}$, where the state of São Paulo is responsible for $54 \%$ of the country's production [1,2].

The fleet growth in the motor pool, undesirable effects of fossil fuel (finite source), and other environmental concerns found ethanol and alcohol sector environmentally friendly fuel alternatives (biofuel) obtained from renewable sources (crops). Therefore, a prominent increase in the demand for ethanol has been observed around the world, especially in 
Brazil for having favorable edapho-climatic conditions for the large-scale cultivation and productive potential of sugarcane crops [3]. Also, sugarcane is a raw material to produce various other by-products for numerous economic sectors, such as food, cosmetics, and energy (by burning bagasse) which further contribute to environmental sustainability [4]. Most of the Brazilian sandy soils are newly occupied by sugarcane cultivation, which were often pasture degraded soil, generally limited with plant nutritional chemical attributes. Thus, adequate nutrient supply is necessary for well-nourished plants that reflect in higher yields with industrial quality and field longevity of sugarcane [5].

Phosphorus $(\mathrm{P})$ is one of the most limiting nutrients in the tropical agricultural system, and at the same time, it is a major challenge to ensure P increased availability in the soil solution [6]. Phosphorus is a primary macronutrient with structural function in plants due to several metabolic processes, such as energy storage and transfer, respiration, nucleic acid synthesis, membrane tuning and stability, enzyme activation and deactivation, redox reactions, and carbohydrate metabolism [7]. It is essential for the synthesis of adenosine triphosphate (ATP) and several other phosphorylated compounds. The importance of $\mathrm{P}$ for plants lies in the fact that it participates directly and indirectly in various metabolic processes, thus acting from root development, tillering, stalk production, besides improving the industrial characteristics of sugarcane [8]. The low $\mathrm{P}$ availability is due to its high adsorption to the clay particles and its precipitation as $\mathrm{Fe}$ and $\mathrm{Al}$ [9] in clay fractions like amorphous hydrated oxides of $\mathrm{Fe}$ and $\mathrm{Al}$, in addition to gibbsite, goethite and kaolinite are responsible for the greater $P$ fixation for plant growth [7]. Approximately $70 \%$ of the phosphate fertilization in sugarcane is not available for plant use, requiring large amounts of fertilizers to achieve high yields [10].

Under tropical soil conditions, the $\mathrm{P}_{2} \mathrm{O}_{5}$ rate recommended for sugarcane production ranges from 130 to $180 \mathrm{~kg} \mathrm{ha}^{-1}$ of $\mathrm{P}_{2} \mathrm{O}_{5}$ in planting [11-13]. Sugarcane can export approximately $30 \mathrm{~kg} \mathrm{P}_{2} \mathrm{O}_{5}$ to produce $100 \mathrm{Mg} \mathrm{ha}^{-1}$ of stalks [14]. The high adsorption of $\mathrm{P}$ on $\mathrm{Fe}$ and $\mathrm{Al}$ oxides/hydroxides, which normally adsorb most of the $\mathrm{P}$ applied in the soil [15], explains the high rate of $P$ applied at sugarcane fields in Brazil. Withers et al. [16] showed that in acid tropical soil, a rate of $80 \mathrm{~kg} \mathrm{ha}^{-1} \mathrm{P}_{2} \mathrm{O}_{5}$ is required to overcome soil $\mathrm{P}$ adsorption. The $\mathrm{P}$ fertilizers, commonly used, are soluble and require extensive amounts of phosphate rock and acids for their production. The conventional soluble P fertilizers should be substituted with renewable sources to build a circular economy, especially considering the recent evidence of excessive $P$ use in tropical areas [16]. Therefore, search for new techniques aiming to increase phosphate fertilization efficiency, especially in regions of less fertility to reduce phosphate fertilization application and cost input, also reduce environmental impacts such as eutrophication of water sources [17]. Microbial inoculants, known as plant growth-promoting bacteria (PGPBs), are promising technologies to reduce the use of conventional synthetic fertilizers [18]. Thus, the association of sugarcane cultivation and PGPBs inoculation is an innovative approach to reduce phosphate fertilization while increasing the sugarcane yield with a positive impact on the circular economy in the Brazilian sugarcane industry, which represents more than one-third of all world production. In this sense, PGPBs could be one of the best alternatives for more sustainable agriculture, as they could promote fertilizer savings and other inputs and increase crop yield [12]. There are reports that these microorganisms can contribute in different ways to plant growth through the synthesis of phytohormones, secondary metabolites, root development, enhanced water and nutrients uptake, and solubilization of nutrients such as P [19] and zinc (Zn) [20]. Also, PGPBs are related to the promotion of biological nitrogen fixation (BNF), induction of tolerance to biotic and abiotic stresses, such as resistance to disease, pathogens attack, and other stresses [21-26].

Azospirillum, Azobacter, Bacillus, Burkholderia, Gluconacetobacter, Herbaspirillum, Pseudomonas, and Rhizobium are among the different genus of PGPBs found or associated with sugarcane crop $[27,28]$. Among these, microbial consortia containing the species, Azospirillum brasilense, and Bacillus subtilis have shown great potential to cycle nutrients from crop residues and restore soil fertility, and improve the sugarcane rhizosphere [12,27]. 
In addition, Bacillus and Pseudomonas genera are among the most efficient solubilizers of inorganic phosphate [29], which could contribute to reducing phosphate application under agricultural systems. Over the last decade, the inoculants market has grown substantially worldwide. In Brazil, an impressive increase in the number of commercialized PGPBs has been seen in the short time of a decade, with commercial inoculants with $A$. brasilense, $B$. subtilis, and P. fluorescens being released. Understanding the success or failure of inoculation requires understanding the complex interactions between plant species, the specificity between hosts and PGPB, and the major microbial communities in the rhizosphere $[30,31]$. Therefore, studies with different PGPB inoculation such as A. brasilense, B. subtilis, and $P$. fluorescens in tropical conditions should be performed since new reports can be largely applicable to other important producing countries. We hypothesized that phosphate fertilization in field-grown sugarcane plants could be improved by A. brasilense, B. subtilis, and $P$. fluorescens inoculations coupled with $\mathrm{P}_{2} \mathrm{O}_{5}$ application rates, providing increased sugarcane yield and industrial quality with reduced $\mathrm{P}_{2} \mathrm{O}_{5}$ rates. Thus, the results would provide a novel perspective for sustainable sugarcane cultivation under tropical conditions by improving $\mathrm{P}$ fertilizer use and uptake without compromising sugarcane yield and quality. The objective of this study was to evaluate the effect of $A$. brasilense, B. subtilis, and $P$. fluorescens inoculation in a single or combined application associated with $\mathrm{P}_{2} \mathrm{O}_{5}$ application rates, on nitrogen $(\mathrm{N})$ and $\mathrm{P}$ leaf concentrations, stalk and sugar yield, and technological quality of sugarcane under tropical conditions.

\section{Materials and Methods}

\subsection{Experimental Area Location}

The experiment was carried out in the $2017 / 2018$ crop season at Limoeiro Farm in an area belonging to Suzanápolis Sugar and Alcohol Mill in Ilha Solteira, located in the northwestern State of São Paulo, Brazil (Appendix A). The geographical coordinates are $20^{\circ} 21^{\prime} 14^{\prime \prime} \mathrm{S}$ latitude and $51^{\circ} 04^{\prime} 51^{\prime \prime} \mathrm{W}$ longitude with $371 \mathrm{~m}$ above sea level. The experimental area has been cultivated with highly degraded pasture (Urochloa brizantha) for over 10 years. The soil of the agricultural area was classified as a Latossolo Vermelho distrófico, from medium to sandy texture according to SiBCS [32], and Rhodic Haplustox according to the Soil Survey Staff [33]. The climate of the region is Aw, according to the Köppen scale, defined as humid tropical with a rainy season in summer and dry in winter. The climatic data regarding the experiment conduction period were properly recorded and are shown in Figure 1. The granulometry analysis showed 777, 98, $125 \mathrm{~g} \mathrm{~kg}^{-1}$ and $747,88,165 \mathrm{~g} \mathrm{~kg}^{-1}$ of sand, silt, and clay at the layers of $0.00-0.25$ and $0.25-0.50 \mathrm{~m}$, respectively, following the methodology of Embrapa [34]. The chemical attributes of the soil were determined before the experiment implementation and are shown in Table 1.

\subsection{Experimental Design and Treatments}

The experimental design was a randomized block design with three replications, arranged in an $8 \times 5$ factorial scheme. Eight inoculations ((1) Control (without inoculation); (2) Inoculation with Azospirillum brasilense; (3) Inoculation with Bacillus subtilis; (4) Inoculation with Pseudomonas fluorescens; (5) Inoculation with $A$. brasilense $+B$. subtilis;

(6) Inoculation with $A$. brasilense $+P$. fluorescens; (7) Inoculation with $B$. subtilis $+P$. fluorescens;

(8) Inoculation with $A$. brasilense $+B$. subtilis $+P$. fluorescens $)$ and five $\mathrm{P}_{2} \mathrm{O}_{5}$ rates $(0,45,90$, 135 , and $180 \mathrm{~kg} \mathrm{ha}^{-1}$ ) hand applied in the planting furrows. These PGPBs are commercial strains used in Brazil [for both A. brasilense (brand name AzoTotal ${ }^{\circledR}$ ), B. subtilis (brand name Vult ${ }^{\circledR}$ ), and P. fluorescens (brand name Audax $\left.{ }^{\circledR}\right)$ ]. These strains when used under similar conditions (Brazilian tropical conditions) have shown positive results in maize and soybean $[35,36]$. Triple superphosphate $\left(46 \%\right.$ of $\left.\mathrm{P}_{2} \mathrm{O}_{5}\right)$ was used as a $\mathrm{P}_{2} \mathrm{O}_{5}$ source, corresponding to $0,25,50,75$, and $100 \%$ of the recommended rate, according to van Raij [11]. The plots had five $5.0 \mathrm{~m}$ long rows with spacing of $1.5 \mathrm{~m}$, and three central rows were considered as useful plot areas. 


\section{Rainfall $\quad \cdots$ O.. Minimum $T \quad-\rightarrow-$ Average $T \quad \rightarrow-$ Maximum T}

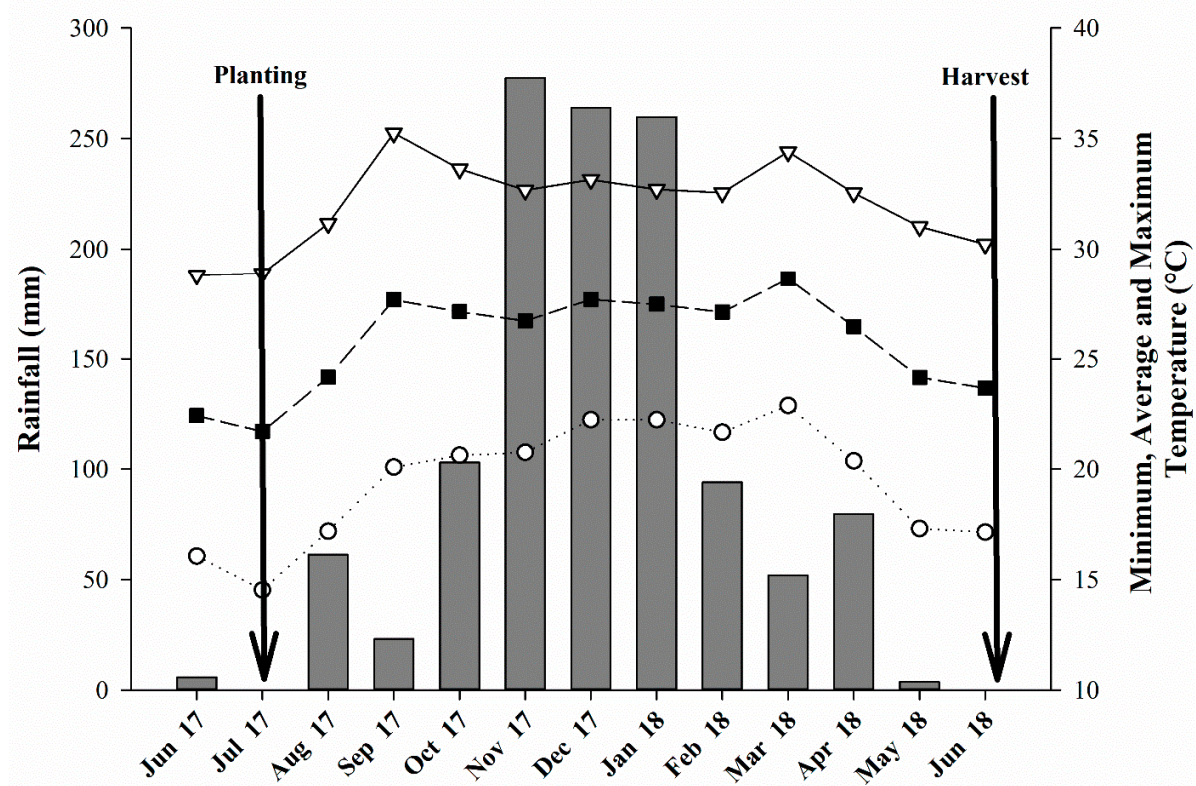

Figure 1. Monthly average rainfall and maximum, average, and minimum temperature recorded during the period of experiment.

Table 1. Initial soil chemical characterization ${ }^{a}$ of the experimental area in the $0.00-0.25$ and $0.25-0.50$ m layers.

\begin{tabular}{|c|c|c|c|c|c|c|c|c|c|c|}
\hline Layer & P Resin & $\mathrm{S}-\mathrm{SO}_{4}$ & OM & $\mathrm{pH}$ & $\mathbf{K}$ & Ca & $\mathrm{Mg}$ & $\mathbf{H}+\mathbf{A l}$ & Al & SB \\
\hline (m) & \multicolumn{2}{|c|}{$\ldots-\ldots-m_{d m}^{-3} \ldots$} & $\mathrm{g} \mathrm{dm}^{-3}$ & $\mathrm{CaCl}_{2}$ & $-\ldots$ & $-\ldots-\ldots$ & $--m m$ & $-3 \ldots$ & $-\ldots$ & $\ldots$ \\
\hline $0.00-0.25$ & 2 & 3 & 13 & 4.7 & 2.6 & 8 & 6 & 20 & 1 & 16.6 \\
\hline $0.25-0.50$ & 2 & 2 & 12 & 4.8 & 2.4 & 9 & 7 & 20 & 2 & 18.4 \\
\hline \multirow{2}{*}{$\begin{array}{l}\text { Layer } \\
\text { (m) }\end{array}$} & $\mathrm{B}^{\mathrm{b}}$ & $\mathrm{Cu}^{\mathrm{c}}$ & \multicolumn{2}{|c|}{$\mathrm{Fe}^{\mathrm{c}}$} & $\mathrm{Mn}^{\mathrm{c}}$ & $\mathrm{Zn}{ }^{\mathrm{c}}$ & \multicolumn{2}{|c|}{ CEC } & - & $\mathrm{m}$ \\
\hline & \multicolumn{4}{|c|}{ - . - . - - - $\mathrm{mg} \mathrm{dm}^{-3} \mathrm{n}_{-}$} & $-\ldots-$ & $-\ldots-\ldots$ & \multicolumn{2}{|c|}{$\mathrm{mmol}^{\mathrm{c}} \mathrm{dm}^{-3}$} & $\%$ & $\%$ \\
\hline $0.00-0.25$ & 0.22 & 0.8 & & & 16.2 & 0.6 & & & 45 & 6 \\
\hline $0.25-0.50$ & 0.22 & 1.0 & & & 8.3 & 0.3 & & & 48 & 10 \\
\hline
\end{tabular}

${ }^{a}$ Methodology proposed by van Raij et al. [11], ${ }^{\mathrm{b}}$ Determined in DTPA (diethylenetriaminepentaacetic acid), ${ }^{c}$ Determined in hot water. OM: organic matter, CEC: cation exchange capacity, SB: sum of bases, V: bases saturation, $\mathrm{m}$ : Al saturation.

\subsection{Experiment Implementation and Conduction}

After initial soil chemical characterization, the soil profile was prepared by applying $1.0 \mathrm{tha}^{-1}$ of dolomitic limestone with engineered cementitious composites (ECC) of $85 \%$ to increase base saturation to $60 \% 15$ days before planting. Also, $1.0 \mathrm{tha}^{-1}$ of gypsum $(15 \%$ of S) was applied to increase sulfur content (S) following the recommendation of van Raij [11] for sugarcane cultivation. Three plowing and one subsoiling operation were performed, followed by the opening of planting furrow at $0.40 \mathrm{~m}$ depth, and insecticide-fipronil (180 $\mathrm{g}$ of active ingredient [a.i.] ha $\left.{ }^{-1}\right)+$ fungicide-pyraclostrobin $\left(125 \mathrm{~g}\right.$ a.i. $\left.\mathrm{ha}^{-1}\right)$ application.

The stems of the RB92579 variety were manually cultivated on 11 July 2017, and sectioned within the planting furrows containing about 22 buds per meter of the furrow. In the planting fertilization, besides the respective rates of $\mathrm{P}_{2} \mathrm{O}_{5}$ of each treatment, $30 \mathrm{~kg} \mathrm{ha}^{-1}$ of $\mathrm{N}$ (as ammonium nitrate- $34 \%$ of $\mathrm{N}$ ) and $120 \mathrm{~kg} \mathrm{ha}^{-1}$ of $\mathrm{K}_{2} \mathrm{O}$ (as potassium chloride $-60 \%$ of $\mathrm{K}_{2} \mathrm{O}$ ) were equally applied to all treatments, based on soil analysis.

The inoculations were performed by spraying PGPBs with a manual sprayer pump at a volume of $200 \mathrm{~L} \mathrm{ha}^{-1}$ in the late afternoon due to the milder temperature in the planting 
furrow. The following rates of liquid inoculant were sprayed: $1.0 \mathrm{~L} \mathrm{ha}^{-1}$ for $A$. brasilense (strains $\mathrm{Ab}-\mathrm{V} 5$ and $\mathrm{Ab}-\mathrm{V} 6$ - the guarantee of $2 \times 10^{8}$ colony forming units (CFU) $\mathrm{mL}^{-1}$ ); $0.5 \mathrm{~L} \mathrm{ha}^{-1}$ for B. subtilis (strain CCTB04 guarantee of $1 \times 10^{8} \mathrm{CFU} \mathrm{mL}^{-1}$ ) and $0.5 \mathrm{~L} \mathrm{ha}^{-1}$ for P. fluorescens (strain CCTB03 guarantee of $1 \times 10^{8} \mathrm{CFU} \mathrm{mL} \mathrm{mL}^{-1}$ ) based on the manufacturer's recommendation. The furrows were mechanically covered after the application of the bacteria (treatments). Due to the absence of rainfall during the experiment implementation, the experimental area was irrigated with sprinkler irrigation (water depth of $30 \mathrm{~mm}$ ) in the very first five days after sugarcane planting.

In the sugarcane tillering phase (at $123 \mathrm{DAP}$ - days after planting) all plots were fertilized with $5.0 \mathrm{~kg} \mathrm{Zn} \mathrm{ha}^{-1}$ (as zinc sulfate-21\% of $\mathrm{Zn}$ and $11 \%$ of S), applied on the soil surface to fulfill zinc-deficient content in the soil.

Control of weeds, pests, and diseases was performed according to crop needs. Hexazinone $\left(320 \mathrm{~g}\right.$ a.i. $\left.\mathrm{ha}^{-1}\right)+2.4 \mathrm{D}\left(967 \mathrm{~g}\right.$ a.i. $\left.\mathrm{ha}^{-1}\right)+$ tebuthiuron $\left(1000 \mathrm{~g}\right.$ a.i. ha $\left.{ }^{-1}\right)$ were applied in pre-emergence (24 DAP). At $110 \mathrm{DAP}, 2.4 \mathrm{D}\left(967 \mathrm{~g}_{\text {a.i. ha }}{ }^{-1}\right)+$ amicarbazone $\left(840 \mathrm{~g}\right.$ a.i. $\left.\mathrm{ha}^{-1}\right)+$ S-Metolachlor $\left(2400 \mathrm{~g}\right.$ a.i. $\left.\mathrm{ha}^{-1}\right)$ were applied. At 101 and $199 \mathrm{DAP}$, insecticides chlorantraniliprole $\left(10 \mathrm{~g}\right.$ a.i. $\left.\mathrm{ha}^{-1}\right)+$ lambda-cyhalothrin $\left(5 \mathrm{~g}\right.$ a.i. ha $\left.{ }^{-1}\right)$ were applied. Aiming at the biological control of the sugarcane borer (Diatraea saccharalis), four releases of Trichogramma galloi $(142,148,213$, and 220 DAP, respectively) and one release of Cotesia flavipes (192 DAP) were performed. At 301 DAP, the Trinexapaque-ethyl ripener ( $275 \mathrm{~g}$ a.i. ha ${ }^{-1}$ ) was applied to induce sugarcane to accumulate sucrose. The plant-cane harvest was carried out manually on 25 June 2018, 349 days after planting.

\subsection{Evaluations}

In the phase of more intense vegetative development of sugarcane (195 DAP), the average third of 15 flag leaves per plot were collected, excluding the midrib by following the methodology of van Raij [11] to determine $\mathrm{N}$ and $\mathrm{P}$ leaf concentrations as described by Malavolta [37]. Briefly, $\mathrm{N}$ was analyzed by sulfuric digestion, distilled by semi-micro Kjeldahl method, and determined by titration with $\mathrm{HCl} 0.05 \mathrm{~N}$. Phosphorus was analyzed by nitro-perchloric digestion and quantified in an Ultraviolet-visible spectroscopy spectrophotometer (UV-VIS-Model Varian Cary-50, manufacturer Varian, city Victoria, country Australia).

At the harvest (349 DAP), the stem mass of each plot was quantified to estimate stalk yield per hectare (STY $-\mathrm{t} \mathrm{ha}^{-1}$ ). Also, at the time of harvest, ten stalks were sampled per plot and sent to the Technological Analysis Laboratory to determine the technological quality of sugarcane according to the methodology defined in the System Sugarcane Payment Plan based on Sucrose Content (SSPPSC) following Fernandes [38] methodology. Fiber (\%), purity apparent of the juice (\%), soluble solids content (Brix-\%), apparent sucrose of juice (Pol-\%), and total recoverable sugar (TRS- $\mathrm{kg} \mathrm{t}^{-1}$; TRS is characterized as the sum of sucrose that can be converted into sugar or alcohol) were determined at Suzanápolis Sugar and Alcohol Mill laboratory. The sequence of technological quality analysis also can be assessed in Lopes et al. [13]. The sugar yield (SUY - $t \mathrm{ha}^{-1}$ ) was obtained by the multiplication of stalk yield per hectare and sugarcane pol $\%$ of each plot, divided by 100 .

\subsection{Statistical Analysis}

The data were submitted to analysis of variance (F test) and Scott Knott test $(p \leq 0.05)$ to group the inoculation means and adjust the regression equations for the effect of $\mathrm{P}_{2} \mathrm{O}_{5}$ rates. Statistical analyses were processed using the R software [39], and graphs were plotted with the aid of SigmaPlot 14.5 software (Systat Software, San Jose, CA, USA).

\section{Results}

\subsection{Nitrogen and $P$ Leaf Concentrations}

Bacterial inoculation and $\mathrm{P}_{2} \mathrm{O}_{5}$ rates did not influence $\mathrm{N}$ leaf concentration in sugarcane crops (Table 2). However, single inoculation with P. fluorescens and co-inoculation 
except $A$. brasilense $+P$. fluorescens provided higher leaf $\mathrm{P}$ concentration regardless of $\mathrm{P}_{2} \mathrm{O}_{5}$ rates applied (Table 2). These inoculations (e.g., P. fluorescens, A. brasilense $+B$. subtilis, and $A$. brasilense $+B$. subtilis $+P$. fluorescens) increased leaf $P$ concentration, varying between $4.4 \%$ and $10.2 \%$ compared to control treatments (Table 2 ).

Table 2. Nitrogen and phosphorus concentrations in sugarcane diagnose leaf.

\begin{tabular}{|c|c|c|}
\hline & Nitrogen & Phosphorus \\
\hline & \multicolumn{2}{|c|}{$\mathrm{g} \mathrm{kg}^{-1}$} \\
\hline \multicolumn{3}{|l|}{$\begin{array}{l}\text { Rates of } \mathrm{P}_{2} \mathrm{O}_{5} \\
\left(\mathrm{~kg} \mathrm{ha}^{-1}\right)\end{array}$} \\
\hline 0 & 20.44 & 2.32 \\
\hline 45 & 20.53 & 2.34 \\
\hline 90 & 20.08 & 2.37 \\
\hline 135 & 20.39 & 2.31 \\
\hline 180 & 20.33 & 2.36 \\
\hline \multicolumn{3}{|l|}{ Inoculation } \\
\hline Control & 19.53 & $2.25 \mathrm{~b}$ \\
\hline Azo & 20.09 & $2.22 \mathrm{~b}$ \\
\hline $\mathrm{Bac}$ & 21.14 & $2.32 \mathrm{~b}$ \\
\hline Pseud & 20.58 & $2.41 \mathrm{a}$ \\
\hline $\mathrm{Azo}+\mathrm{Bac}$ & 20.03 & $2.37 \mathrm{a}$ \\
\hline Azo + Pseud & 20.36 & $2.31 \mathrm{~b}$ \\
\hline Bac + Pseud & 20.65 & $2.48 \mathrm{a}$ \\
\hline \multicolumn{2}{|l|}{$\mathrm{F}$ test } & $2.35 \mathrm{a}$ \\
\hline Rates of $\mathrm{P}_{2} \mathrm{O}_{5}(\mathrm{D})$ & ns & ns \\
\hline Inoculation (I) & ns & * \\
\hline $\mathrm{D} \times \mathrm{I}$ & ns & ns \\
\hline Overall Average & 20.36 & 2.34 \\
\hline Standard error & 0.34 & 0.05 \\
\hline
\end{tabular}

Averages followed by the same letter in the columns belong to the same group by Scott and Knott test at $5 \%$ probability. Control (without inoculation); Azo (Azospirillum brasilense); Bac (Bacillus subtilis); Pseud (Pseudomonas fluorescens); Azo + Bac (A. brasilense + B. subtilis); Azo + Pseud (A. brasilense + P. fluorescens); Bac + Pseud (B. subtilis + P. fluorescens); Azo + Bac + Pseud (A. brasilense + B. subtilis + P. fluorescens). CV: coefficient of variation. * and ns: significant at $5 \%$ at $p<0.05$ and $p>0.01$ and not significant, respectively.

\subsection{Sugarcane Technological Quality}

Interaction between $\mathrm{P}_{2} \mathrm{O}_{5}$ rates and inoculations was significant for fiber content, Brix, Pol, and TRS (Table 3). However, the apparent purity of juice was not influenced by any of the variable sources and their interactions (Table 3). Regarding fiber content, there was a nonlinear adjustment for $A$. brasilense (up to $94 \mathrm{~kg} \mathrm{P}_{2} \mathrm{O}_{5} \mathrm{ha}^{-1}$ ), B. subtilis (up to $103 \mathrm{~kg} \mathrm{P}_{2} \mathrm{O}_{5}$ ha ${ }^{-1}$ ), A. brasilense $+B$. subtilis (up to $94 \mathrm{~kg} \mathrm{P}_{2} \mathrm{O}_{5} \mathrm{ha}^{-1}$ ), A. brasilense $+P$. fluorescens (up to $101 \mathrm{~kg} \mathrm{P}_{2} \mathrm{O}_{5} \mathrm{ha}^{-1}$ ) and $A$. brasilense + B. subtilis + P. fluorescens (up to $77 \mathrm{~kg}_{2} \mathrm{O}_{5} \mathrm{ha}^{-1}$ ) inoculations (Figure 2a). Inoculation with B. subtilis $+P$. fluorescens and control treatment indicated linear adjustment with increasing $\mathrm{P}_{2} \mathrm{O}_{5}$ rates whereas $P$. fluorescens decreased with increasing $\mathrm{P}_{2} \mathrm{O}_{5}$ rates (Figure 2a). Fiber content fluctuated with all applied $\mathrm{P}_{2} \mathrm{O}_{5}$ rates and inoculations however, the lowest content was associated with high $\mathrm{P}_{2} \mathrm{O}_{5}$ rates $\left(180 \mathrm{~kg} \mathrm{ha}^{-1}\right)$ along single inoculation of $A$. brasilense, B. subtilis, and P. fluorescens and co-inoculation of A. brasilense $+P$. fluorescens and $A$. brasilense $+B$. subtilis + . fluorescens (Table 4 ). 
Table 3. Indicators of technological quality, stalk yield (STY) and sugar yield (SUY) of RB92579 sugarcane variety.

\begin{tabular}{|c|c|c|c|c|c|c|c|}
\hline & Fiber & Purity & Brix & Pol & TRS & STY & SUY \\
\hline & $\%$ & $\%$ & $\%$ & $\%$ & $\mathrm{~kg} \mathrm{t}^{-1}$ & tha $a^{-1}$ & tha $a^{-1}$ \\
\hline \multicolumn{8}{|l|}{$\begin{array}{l}\text { Rates of } \mathrm{P}_{2} \mathrm{O}_{5} \\
\quad\left(\mathrm{~kg} \mathrm{ha}^{-1}\right)\end{array}$} \\
\hline 0 & 10.19 & 81.58 & 19.57 & 14.15 & 142.62 & 175.31 & 24.80 \\
\hline 45 & 10.58 & 82.12 & 20.16 & 14.53 & 145.20 & 177.60 & 25.80 \\
\hline 90 & 10.77 & 81.28 & 20.34 & 14.31 & 140.41 & 180.11 & 25.78 \\
\hline 135 & 10.59 & 81.03 & 20.15 & 14.33 & 140.95 & 181.14 & 25.96 \\
\hline 180 & 10.41 & 82.84 & 19.59 & 13.96 & 143.99 & 189.99 & 26.41 \\
\hline \multicolumn{8}{|l|}{ Inoculation } \\
\hline Control & 10.45 & 82.27 & 19.89 & 14.27 & 142.51 & 167.58 & 23.85 \\
\hline Azo & 10.65 & 83.72 & 19.86 & 14.29 & 145.26 & 177.23 & 25.41 \\
\hline $\mathrm{Bac}$ & 10.48 & 81.21 & 19.74 & 13.91 & 140.60 & 177.11 & 24.55 \\
\hline Pseud & 10.23 & 82.05 & 20.20 & 14.71 & 143.37 & 185.13 & 27.42 \\
\hline $\mathrm{Azo}+\mathrm{Bac}$ & 10.89 & 81.60 & 20.29 & 14.13 & 140.70 & 186.21 & 26.19 \\
\hline Azo + Pseud & 10.43 & 81.85 & 19.82 & 14.35 & 142.14 & 189.05 & 27.13 \\
\hline Bac + Pseud & 10.37 & 80.74 & 19.88 & 14.20 & 142.62 & 196.78 & 27.77 \\
\hline $\begin{array}{c}\mathrm{Azo}+\mathrm{Bac}+\text { Pseud } \\
\text { F test }\end{array}$ & 10.58 & 80.72 & 20.03 & 14.18 & 143.87 & 167.56 & 23.68 \\
\hline Rates of $\mathrm{P}_{2} \mathrm{O}_{5}(\mathrm{D})$ & $* *$ & ns & $* *$ & $* *$ & $* *$ & $\mathrm{~ns}$ & $\mathrm{~ns}$ \\
\hline Inoculation (I) & $* *$ & ns & $* *$ & $* *$ & $* *$ & $* *$ & $* *$ \\
\hline $\mathrm{D} \times \mathrm{I}$ & $* *$ & ns & $* *$ & $* *$ & $* *$ & $* *$ & $* *$ \\
\hline Overall Average & 10.51 & 81.77 & 19.96 & 14.25 & 142.63 & 180.83 & 25.75 \\
\hline Standard error & 0.07 & 0.86 & 0.09 & 0.12 & 0.49 & 5.30 & 0.75 \\
\hline CV $(\%)$ & 2.59 & 4.09 & 1.87 & 3.23 & 1.33 & 13.11 & 13.10 \\
\hline
\end{tabular}

TRS: Total recoverable sugar. Averages followed by the same letter in the columns belong to the same group by the Scott and Knott test, at 5\% probability. Control (without inoculation); Azo (Azospirillum brasilense); Bac (Bacillus subtilis); Pseud (Pseudomonas fluorescens); Azo + Bac (A. brasilense + B. subtilis); Azo + Pseud (A. brasilense + P. fluorescens); Bac + Pseud (B. subtilis + P. fluorescens); Azo + Bac + Pseud (A. brasilense + B. subtilis + P. fluorescens). $\mathrm{CV}$ : coefficient of variation. ${ }^{* *}$ and ns: significant at $1 \%$ at $p<0.01$ and not significant, respectively.

Control: $\mathrm{y}-0.0065 \mathrm{x}+9.8673\left(\mathrm{R}^{2}-0.99^{* *}\right)$

Azo: $y=-0.0001 x^{2}+0.0187 x+10.2493\left(R^{2}-0.64 * *\right)$

Bac: $y^{-}-0.0001 x^{2}+0.0206 x+9.9443\left(R^{2}-0.79 * *\right)$

Peud: $y=-0.0041 x+10.6020\left(\mathrm{R}^{2}-1,0^{2}+1\right)$

Azo+Bac: $y=-0.00008 x^{2}+0.0151 x+10.4738\left(R^{2}=0.74^{* *}\right)$

A\% Pseud: $y-0.0001 x^{2}+0.0201 x+9.9201\left(R^{2}-0.71 * *\right)$

Bac+Pseud: $y=0.0040 x+10.0100\left(R^{2}=0.96^{* *}\right)$

Azo | Bac | Pseud: $y-0.00006 \mathrm{x}^{2}|0.0092 \mathrm{x}| 10.4463\left(\mathrm{R}^{2}-0.87^{* * *}\right.$

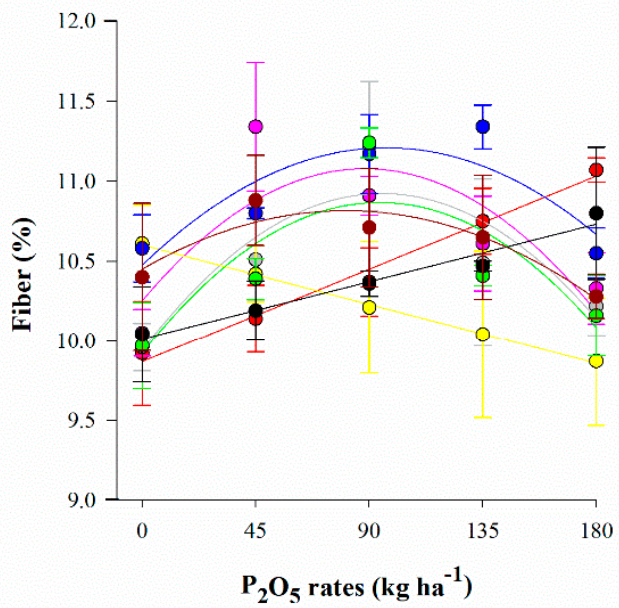

(a)

Control: $y-19.9 \mathrm{~ns}$

$\Lambda z o: y=-0.00009 x^{2}+0.0084 x+20.1805\left(R^{2}=0.82 * *\right)$

Bac: $y--0.0001 \mathrm{x}^{2}+0.0182 \mathrm{x}+19.3049\left(\mathrm{R}^{2}-0.79^{* *}\right)$

Azo l13ac: $y=-0.0002 \mathrm{x}^{2}+0.0325 \mathrm{x}+1935875\left(\mathrm{R}^{2}-0.83^{* *}\right)$

Azo Pseud: $y-0.0085 x+19.0593\left(R^{2}-0.88^{* *}\right)$

Bac+Pscud: $y=-0.0065 x+20.4673\left(R^{2}=0.99 * *\right)$

A\%o+BactPseud: $y-0.0002 x^{2}+0.0414 x+18.8244\left(R^{2}-0.90 * *\right)$

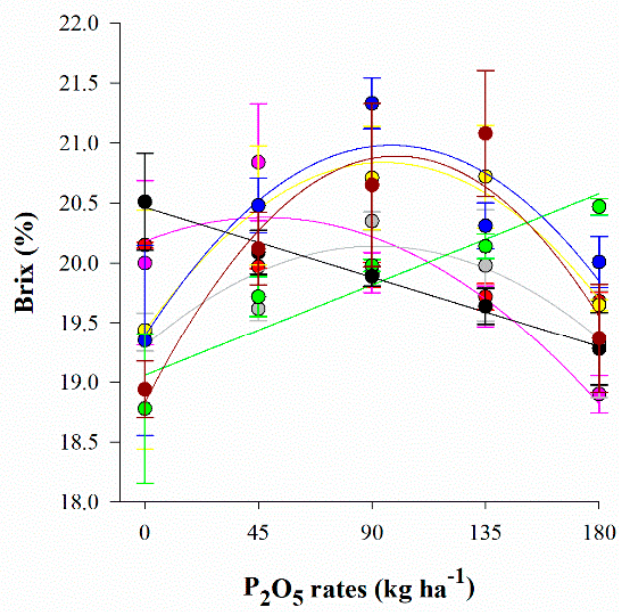

Figure 2. Cont. 
- Control: $\mathrm{y}=-0.0039 \mathrm{x}+14.6220\left(\mathrm{R}^{2}=0.87^{*}\right)$

Azo: $y=-0.0069 x+14.9120\left(R^{2}-0.51^{* *}\right)$

Bac: $y--0.0061 x+13.3547\left(R^{2}-0.95 * *\right)$

Pscud: $y--0.0002 x^{2}+0.0392 x+13.6433\left(R^{2}-0.68^{* *}\right)$

Azo+Bac: $y^{-}-0.0001 x^{2}+0.0247 x+13.4363\left(R^{2}-0.72 * 0\right)$

Azo+Bac. $y=0.001 x^{2}+0.0247 x+13.4363\left(R^{2}-0.72^{* * *}\right)$

Azac Pseut $y=-0.0071 x+14.8420\left(R^{2}-0.88^{*}\right)$

Azo+Bac+Pseud: $y--0.0002 x^{2}+0.0244 x+13.8386\left(R^{2}-0.70^{* * *}\right)$

(c)

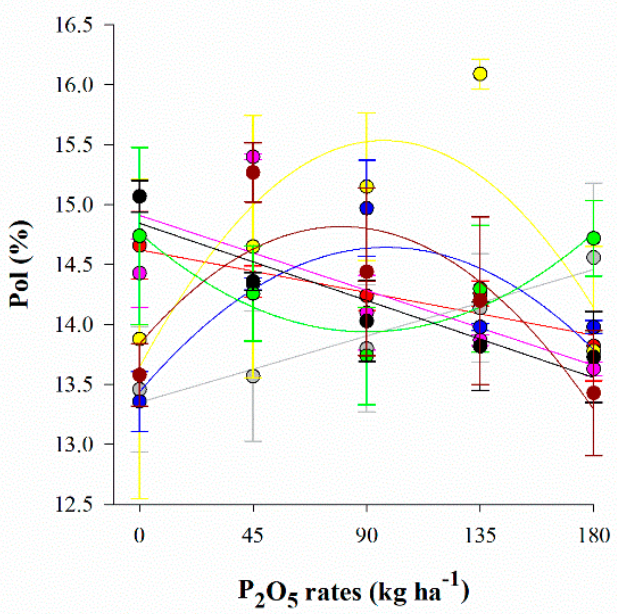

Figure 2. Interaction between $\mathrm{P}_{2} \mathrm{O}_{5}$ rates and inoculations for fiber (a), soluble solids content (Brix) (b) and apparent sucrose of juice ( $\mathrm{Pol})(\mathbf{c})$ content of sugarcane. Error bars indicate the standard deviation of the mean $(n=3) .{ }^{* *},{ }^{*}$ and ns: significant at $1 \%$ at $p<0.01,5 \%$ at $p<0.05$ and $p>0.01$ and not significant, respectively.

The soluble solids content of juice responded non-linearly to increasing $\mathrm{P}_{2} \mathrm{O}_{5}$ rates in $A$. brasilense (up to $47 \mathrm{~kg} \mathrm{P}_{2} \mathrm{O}_{5} \mathrm{ha}^{-1}$ ), B. subtilis (up to $91 \mathrm{~kg} \mathrm{P}_{2} \mathrm{O}_{5} \mathrm{ha}^{-1}$ ), P. fluorescens (up to $74 \mathrm{~kg} \mathrm{P}_{2} \mathrm{O}_{5} \mathrm{ha}^{-1}$ ), A. brasilense $+B$. subtilis (up to $81 \mathrm{~kg} \mathrm{P}_{2} \mathrm{O}_{5} \mathrm{ha}^{-1}$ ) and $A$. brasilense $+B$. subtilis + P. fluorescens (up to $104 \mathrm{~kg} \mathrm{P}_{2} \mathrm{O}_{5} \mathrm{ha}^{-1}$ ) inoculations (Figure $2 \mathrm{~b}$ ). Inoculation with $A$. brasilense $+P$. fluorescens showed linear adjustment with increasing $\mathrm{P}_{2} \mathrm{O}_{5}$ rates while $B$. subtilis $+P$. fluorescens decreased with increasing $\mathrm{P}_{2} \mathrm{O}_{5}$ rates (Figure $2 \mathrm{~b}$ ). Apparent sucrose of juice responded non-linearly to increasing $\mathrm{P}_{2} \mathrm{O}_{5}$ rates in $P$. fluorescens (up to $98 \mathrm{~kg} \mathrm{P}_{2} \mathrm{O}_{5} \mathrm{ha}^{-1}$ ), A. brasilense + B. subtilis (up to $124 \mathrm{~kg}_{2} \mathrm{O}_{5} \mathrm{ha}^{-1}$ ), A. brasilense + $P$. fluorescens $\left(\mathrm{Pmin}=91.5 \mathrm{~kg} \mathrm{P}_{2} \mathrm{O}_{5} \mathrm{ha}^{-1}\right.$ ), and $A$. brasilense $+B$. subtilis $+P$. fluorescens (up to $61 \mathrm{~kg} \mathrm{P}_{2} \mathrm{O}_{5} \mathrm{ha}^{-1}$ ) inoculations (Figure $2 \mathrm{c}$ ). Inoculation with $B$. subtilis showed linear adjustment with increasing $\mathrm{P}_{2} \mathrm{O}_{5}$ rates while $A$. brasilense, $B$. subtilis $+P$. fluorescens, and control treatment decreased with increasing $\mathrm{P}_{2} \mathrm{O}_{5}$ rates (Figure $2 \mathrm{c}$ ). Total recoverable sugar responded non-linearly to increasing $\mathrm{P}_{2} \mathrm{O}_{5}$ rates in $\mathrm{B}$. subtilis $\left(\mathrm{Pmin}=77 \mathrm{~kg} \mathrm{P}_{2} \mathrm{O}_{5}\right.$ ha $\left.{ }^{-1}\right)$, A. brasilense $+P$. fluorescens (Pmin $=89 \mathrm{~kg} \mathrm{P}_{2} \mathrm{O}_{5} \mathrm{ha}^{-1}$ ), B. subtilis + P. fluorescens $\left(\right.$ Pmin $\left.=122 \mathrm{~kg} \mathrm{P}_{2} \mathrm{O}_{5} \mathrm{ha}^{-1}\right)$, A. brasilense + B. subtilis (up to $\left.103 \mathrm{~kg} \mathrm{P}_{2} \mathrm{O}_{5} \mathrm{ha}^{-1}\right)$ and $A$. brasilense + B. subtilis + P. fluorescens (up to $87 \mathrm{~kg} \mathrm{P}_{2} \mathrm{O}_{5} \mathrm{ha}^{-1}$ ) inoculations) (Figure $3 \mathrm{a}$ ). In general, under low (45 kg ha $\left.{ }^{-1}\right)$, average (90 and $\left.135 \mathrm{~kg} \mathrm{ha}^{-1}\right)$, and high $\left(180 \mathrm{~kg} \mathrm{ha}^{-1}\right) \mathrm{P}_{2} \mathrm{O}_{5}$ rates associated with single and combined inoculations with $A$. brasilense, B. subtilis, and $P$. fluorescens provided greater Brix, Pol, and TRS when compared to control treatment (Table 4).

\subsection{Stalk and Sugar Yield}

Interaction between $\mathrm{P}_{2} \mathrm{O}_{5}$ rates and inoculations was significant for STY and SUY (Table 2). There was a linear adjustment with increasing $\mathrm{P}_{2} \mathrm{O}_{5}$ rates for control treatment, $P$. fluorescens and B. subtilis + P. fluorescens inoculation on STY, whereas a non-linear adjustment was verified for $B$. subtilis (up to $96 \mathrm{~kg} \mathrm{P}_{2} \mathrm{O}_{5} \mathrm{ha}^{-1}$ ), and $A$. brasilense $+P$. fluorescens (up to $112 \mathrm{~kg} \mathrm{P}_{2} \mathrm{O}_{5} \mathrm{ha}^{-1}$ ) (Figure $3 \mathrm{~b}$ ). In general, we did not verify a specific trend of inoculations however low (45 kg ha ${ }^{-1}$ ) and average (90 and $\left.135 \mathrm{~kg} \mathrm{ha}^{-1}\right) \mathrm{P}_{2} \mathrm{O}_{5}$ rates along with single and/or combined inoculations of $A$. brasilense, B. subtilis, and $P$. fluorescens except the combination of all three bacteria provided greater STY compared to control treat- 
ment (Figure 3b). The highest STY was verified with $A$. brasilense $+B$. subtilis inoculation associated with $45 \mathrm{~kg} \mathrm{P}_{2} \mathrm{O}_{5}$ ha ha $^{-1}$ providing $211 \mathrm{t} \mathrm{STY} \mathrm{ha} \mathrm{ha}{ }^{-1}$, reflecting an increase of $38 \%$ compared to control treatment (Table 5). Also, inoculation with A. brasilense $+B$. subtilis associated with $45 \mathrm{~kg} \mathrm{P}_{2} \mathrm{O}_{5}$ ha ha ${ }^{-1}$ provided an increase of $11.1 \%$ when compared to the average of all inoculations and control treatments associated with $180 \mathrm{~kg} \mathrm{P}_{2} \mathrm{O}_{5} \mathrm{ha} \mathrm{ha}^{-1}$ (Table 5).

Table 4. Interaction of inoculation and $\mathrm{P}_{2} \mathrm{O}_{5}$ rates for fiber, Brix and pol in RB92579 sugarcane variety.

\begin{tabular}{|c|c|c|c|c|c|}
\hline \multirow[b]{3}{*}{ Inoculation } & \multicolumn{5}{|c|}{ Fiber $(\%)$} \\
\hline & \multicolumn{5}{|c|}{ Rates of $\mathrm{P}_{2} \mathrm{O}_{5}\left(\mathrm{~kg} \mathrm{ha}^{-1}\right)$} \\
\hline & 0 & 45 & 90 & 135 & 180 \\
\hline Control & $9.92 \mathrm{~b}$ & $10.14 \mathrm{c}$ & $10.37 \mathrm{~b}$ & $10.75 \mathrm{~b}$ & $11.07 \mathrm{a}$ \\
\hline Azo & $10.05 \mathrm{~b}$ & $11.34 \mathrm{a}$ & $10.91 \mathrm{a}$ & $10.61 \mathrm{~b}$ & $10.33 \mathrm{~b}$ \\
\hline $\mathrm{Bac}$ & $9.96 \mathrm{~b}$ & $10.51 \mathrm{c}$ & $11.22 \mathrm{a}$ & $10.49 \mathrm{~b}$ & $10.21 \mathrm{~b}$ \\
\hline Pseud & $10.61 \mathrm{a}$ & $10.42 \mathrm{c}$ & $10.21 \mathrm{~b}$ & $10.04 \mathrm{~b}$ & $9.87 \mathrm{~b}$ \\
\hline $\mathrm{Azo}+\mathrm{Bac}$ & $10.58 \mathrm{a}$ & $10.80 \mathrm{~b}$ & $11.17 \mathrm{a}$ & $11.34 \mathrm{a}$ & $10.55 \mathrm{a}$ \\
\hline Azo + Pseud & $9.97 \mathrm{~b}$ & $10.39 \mathrm{c}$ & $11.24 \mathrm{a}$ & $10.41 \mathrm{~b}$ & $10.16 \mathrm{~b}$ \\
\hline Bac + Pseud & $10.04 \mathrm{~b}$ & $10.19 \mathrm{c}$ & $10.36 \mathrm{~b}$ & $10.47 \mathrm{~b}$ & $10.80 \mathrm{a}$ \\
\hline Azo + Bac + Pseud & $10.40 \mathrm{a}$ & $10.88 \mathrm{~b}$ & $10.71 \mathrm{~b}$ & $10.65 \mathrm{~b}$ & $10.28 \mathrm{~b}$ \\
\hline \multirow[t]{3}{*}{ Standard error } & \multicolumn{5}{|c|}{0.16} \\
\hline & \multicolumn{5}{|c|}{ Brix (\%) } \\
\hline & \multicolumn{5}{|c|}{ Rates of $\mathrm{P}_{2} \mathrm{O}_{5}\left(\mathrm{~kg} \mathrm{ha}^{-1}\right)$} \\
\hline Inoculation & 0 & 45 & 90 & 135 & 180 \\
\hline Control & $20.15 \mathrm{a}$ & $19.97 b$ & $19.90 \mathrm{c}$ & $19.72 \mathrm{~b}$ & $19.68 \mathrm{~b}$ \\
\hline Azo & $20.00 \mathrm{a}$ & $20.84 \mathrm{a}$ & 19.92 c & $19.64 \mathrm{~b}$ & $18.90 \mathrm{~b}$ \\
\hline $\mathrm{Bac}$ & $19.42 \mathrm{~b}$ & $19.62 b$ & $20.35 c$ & $19.98 \mathrm{~b}$ & $19.33 \mathrm{~b}$ \\
\hline Pseud & $19.44 \mathrm{~b}$ & $20.48 \mathrm{a}$ & $20.71 b$ & $20.72 \mathrm{a}$ & $19.65 \mathrm{~b}$ \\
\hline $\mathrm{Azo}+\mathrm{Bac}$ & $19.35 \mathrm{~b}$ & $20.48 \mathrm{a}$ & $21.33 \mathrm{a}$ & $20.31 b$ & $20.01 \mathrm{a}$ \\
\hline Azo + Pseud & $18.78 \mathrm{c}$ & $19.72 b$ & $19.98 \mathrm{c}$ & $20.14 b$ & $20.47 \mathrm{a}$ \\
\hline Bac + Pseud & $20.51 \mathrm{a}$ & $20.09 \mathrm{~b}$ & $19.89 \mathrm{c}$ & $19.64 \mathrm{~b}$ & $19.28 \mathrm{~b}$ \\
\hline $\mathrm{Azo}+\mathrm{Bac}+$ Pseud & $18.94 \mathrm{c}$ & $20.12 b$ & $20.65 b$ & $21.08 \mathrm{a}$ & $19.37 \mathrm{~b}$ \\
\hline \multirow[t]{3}{*}{ Standard error } & \multicolumn{5}{|c|}{0.22} \\
\hline & \multicolumn{5}{|c|}{ Pol (\%) } \\
\hline & \multicolumn{5}{|c|}{ Rates of $\mathrm{P}_{2} \mathrm{O}_{5}\left(\mathrm{~kg} \mathrm{ha}^{-1}\right)$} \\
\hline Inoculation & 0 & 45 & 90 & 135 & 180 \\
\hline Control & $14.66 \mathrm{a}$ & $14.36 \mathrm{~b}$ & $14.24 \mathrm{~b}$ & $14.26 \mathrm{~b}$ & $13.82 \mathrm{~b}$ \\
\hline Azo & $14.43 \mathrm{a}$ & $15.40 \mathrm{a}$ & $14.10 \mathrm{~b}$ & $13.87 \mathrm{~b}$ & $13.63 \mathrm{~b}$ \\
\hline $\mathrm{Bac}$ & $13.46 \mathrm{~b}$ & $13.57 \mathrm{~b}$ & $13.81 \mathrm{~b}$ & $14.14 \mathrm{~b}$ & $14.56 \mathrm{a}$ \\
\hline Pseud & $13.88 \mathrm{~b}$ & $14.65 \mathrm{~b}$ & $15.15 \mathrm{a}$ & $16.10 \mathrm{a}$ & $13.78 \mathrm{~b}$ \\
\hline $\mathrm{Azo}+\mathrm{Bac}$ & $13.36 \mathrm{~b}$ & $14.34 \mathrm{~b}$ & $14.97 \mathrm{a}$ & $13.98 \mathrm{~b}$ & $13.98 \mathrm{~b}$ \\
\hline Azo + Pseud & $14.74 \mathrm{a}$ & $14.26 \mathrm{~b}$ & $13.74 \mathrm{~b}$ & $14.30 \mathrm{~b}$ & $14.72 \mathrm{a}$ \\
\hline Bac + Pseud & $15.07 \mathrm{a}$ & $14.36 \mathrm{~b}$ & $14.03 \mathrm{~b}$ & $13.82 \mathrm{~b}$ & $13.73 \mathrm{~b}$ \\
\hline Azo + Bac + Pseud & $13.58 \mathrm{~b}$ & $15.27 \mathrm{a}$ & $14.44 \mathrm{~b}$ & $14.20 \mathrm{~b}$ & $13.43 \mathrm{~b}$ \\
\hline Standard error & \multicolumn{5}{|c|}{0.27} \\
\hline
\end{tabular}

Averages followed by the same letter in the columns belong to the same group by the Scott and Knott test at 5\% probability. Control (without inoculation); Azo (Azospirillum brasilense); Bac (Bacillus subtilis); Pseud (Pseudomonas fluorescens); Azo + Bac (A. brasilense + B. subtilis); Azo + Pseud (A. brasilense + P. fluorescens); Bac + Pseud (B. subtilis + P. fluorescens); Azo + Bac + Pseud (A. brasilense + B. subtilis + P. fluorescens). 

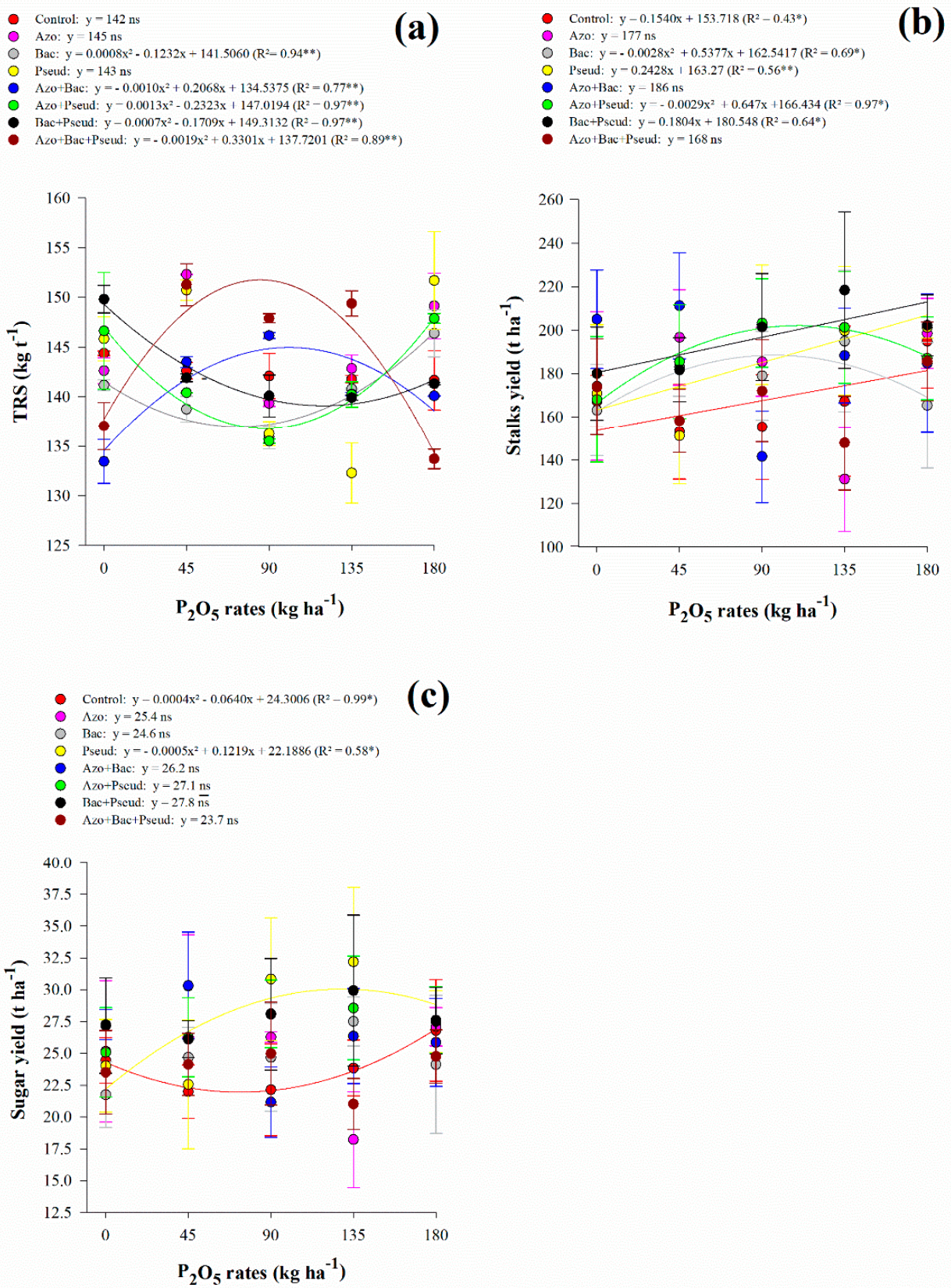

(c)

Figure 3. Interaction between $\mathrm{P}_{2} \mathrm{O}_{5}$ rates and inoculations in total recoverable sugars (TRS) (a), stalks yield (STY) (b) and sugar yield (SUY) (c). Error bars indicate the standard deviation of the mean $(n=3) .{ }^{* *},{ }^{*}$ and ns: significant at $1 \%$ at $p<0.01,5 \%$ at $p<0.05$ and $p>0.01$ and not significant, respectively.

Similarly, SUY was greater under low $\left(45 \mathrm{~kg} \mathrm{ha}^{-1}\right)$ and average (90 and $\left.135 \mathrm{~kg} \mathrm{ha}^{-1}\right)$ $\mathrm{P}_{2} \mathrm{O}_{5}$ rates associated with single and combined inoculations of $A$. brasilense, $B$. subtilis, and $P$. fluorescens except for the combination of all three bacteria when compared to control treatment (Figure 3c). The highest SUY (32.19 $\mathrm{t} \mathrm{ha}^{-1}$ ) was verified with $P$. fluorescens inoculation under $135 \mathrm{~kg} \mathrm{P}_{2} \mathrm{O}_{5} \mathrm{ha}^{-1}$ followed by the inoculation of $A$. brasilense $+B$. subtilis associated with $45 \mathrm{~kg} \mathrm{P}_{2} \mathrm{O}_{5} \mathrm{ha}^{-1}$ (30.33 $\mathrm{t} \mathrm{ha}^{-1}$ ) (Figure 3c). These treatments provided an increase of $21.9 \%$ (P. fluorescens associated with $135 \mathrm{~kg} \mathrm{P}_{2} \mathrm{O}_{5} \mathrm{ha}^{-1}$ ) and $14.9 \%$ (A. brasilense + B. subtilis associated with $45 \mathrm{~kg} \mathrm{P}_{2} \mathrm{O}_{5} \mathrm{ha}^{-1}$ ) when compared to the average of all inoculations and control treatment associated with $180 \mathrm{~kg} \mathrm{P}_{2} \mathrm{O}_{5} \mathrm{ha}^{-1}$ (Table 5). In complement, SUY showed a non-linear adjustment for control treatment $\left(\mathrm{Pmin}=80 \mathrm{~kg} \mathrm{P}_{2} \mathrm{O}_{5} \mathrm{ha}^{-1}\right)$ and $P$. fluorescens inoculation (up to $122 \mathrm{~kg} \mathrm{P}_{2} \mathrm{O}_{5} \mathrm{ha}^{-1}$ ) (Table 5). 
Table 5. Interaction of inoculation and $\mathrm{P}_{2} \mathrm{O}_{5}$ rates for total recoverable sugar (TRS), stalk yield (STY) and sugar yield (SUY) of RB92579 sugarcane variety.

\begin{tabular}{|c|c|c|c|c|c|}
\hline \multirow[b]{3}{*}{ Inoculation } & \multicolumn{5}{|c|}{ TRS $\left(\mathrm{kg} \mathrm{t}^{-1}\right)$} \\
\hline & \multicolumn{5}{|c|}{ Rates of $\mathrm{P}_{2} \mathrm{O}_{5}\left(\mathrm{~kg} \mathrm{ha}^{-1}\right)$} \\
\hline & 0 & 45 & 90 & 135 & 180 \\
\hline Control & $144.38 \mathrm{c}$ & $142.63 \mathrm{~b}$ & $142.10 \mathrm{~b}$ & $141.78 \mathrm{~b}$ & $141.68 c$ \\
\hline Azo & $142.64 \mathrm{c}$ & $152.33 \mathrm{a}$ & $139.33 \mathrm{c}$ & $142.86 \mathrm{~b}$ & $149.15 \mathrm{~b}$ \\
\hline $\mathrm{Bac}$ & $141.18 \mathrm{c}$ & $138.75 \mathrm{c}$ & $135.90 \mathrm{~d}$ & $140.81 \mathrm{~b}$ & $146.39 \mathrm{~b}$ \\
\hline Pseud & $145.84 \mathrm{~b}$ & $150.74 \mathrm{a}$ & $136.27 \mathrm{~d}$ & $132.29 \mathrm{c}$ & $151.71 \mathrm{a}$ \\
\hline $\mathrm{Azo}+\mathrm{Bac}$ & $133.45 \mathrm{e}$ & $143.51 \mathrm{~b}$ & $146.18 \mathrm{a}$ & $140.28 \mathrm{~b}$ & $140.10 \mathrm{c}$ \\
\hline Azo + Pseud & $146.64 \mathrm{~b}$ & $140.43 \mathrm{c}$ & $135.50 \mathrm{~d}$ & $140.24 \mathrm{~b}$ & $147.89 \mathrm{~b}$ \\
\hline Bac + Pseud & $149.83 \mathrm{a}$ & $141.92 \mathrm{~b}$ & $140.10 \mathrm{c}$ & $139.93 \mathrm{~b}$ & $141.33 c$ \\
\hline $\mathrm{Azo}+\mathrm{Bac}+$ Pseud & $137.04 \mathrm{~d}$ & $151.29 \mathrm{a}$ & $147.90 \mathrm{a}$ & $149.40 \mathrm{a}$ & $133.71 \mathrm{~d}$ \\
\hline \multirow[t]{3}{*}{ Standard error } & \multicolumn{5}{|c|}{1.09} \\
\hline & \multicolumn{5}{|c|}{$\operatorname{STY}\left(\mathrm{t} \mathrm{ha}^{-1}\right)$} \\
\hline & \multicolumn{5}{|c|}{ Rates of $\mathrm{P}_{2} \mathrm{O}_{5}\left(\mathrm{~kg} \mathrm{ha}^{-1}\right)$} \\
\hline Inoculation & 0 & 45 & 90 & 135 & 180 \\
\hline Control & $167.30 \mathrm{a}$ & $153.13 \mathrm{~b}$ & $155.33 \mathrm{~b}$ & $167.25 \mathrm{~b}$ & $194.90 \mathrm{a}$ \\
\hline Azo & $174.20 \mathrm{a}$ & $196.68 \mathrm{a}$ & $185.48 \mathrm{a}$ & $131.25 \mathrm{~b}$ & $198.55 \mathrm{a}$ \\
\hline $\mathrm{Bac}$ & $163.15 \mathrm{a}$ & $182.98 \mathrm{a}$ & $179.10 \mathrm{a}$ & $194.90 \mathrm{a}$ & $165.43 \mathrm{a}$ \\
\hline Pseud & $170.85 \mathrm{a}$ & $151.25 \mathrm{~b}$ & $202.55 \mathrm{a}$ & $199.73 \mathrm{a}$ & $201.25 \mathrm{a}$ \\
\hline $\mathrm{Azo}+\mathrm{Bac}$ & $205.03 \mathrm{a}$ & $211.28 \mathrm{a}$ & $141.65 \mathrm{~b}$ & $188.33 \mathrm{a}$ & $184.78 \mathrm{a}$ \\
\hline Azo + Pseud & $168.08 \mathrm{a}$ & $185.53 \mathrm{a}$ & $203.30 \mathrm{a}$ & $201.28 \mathrm{a}$ & $187.08 \mathrm{a}$ \\
\hline Bac + Pseud & $180.03 \mathrm{a}$ & $181.75 \mathrm{a}$ & $201.43 \mathrm{a}$ & $218.43 \mathrm{a}$ & $202.28 \mathrm{a}$ \\
\hline $\mathrm{Azo}+\mathrm{Bac}+$ Pseud & $173.88 \mathrm{a}$ & $158.25 b$ & $172.03 \mathrm{~b}$ & $147.95 \mathrm{~b}$ & $185.68 a$ \\
\hline \multirow[t]{3}{*}{ Standard error } & \multicolumn{5}{|c|}{11.85} \\
\hline & \multicolumn{5}{|c|}{ SUY (t ha $\left.{ }^{-1}\right)$} \\
\hline & \multicolumn{5}{|c|}{ Rates of $\mathrm{P}_{2} \mathrm{O}_{5}\left(\mathrm{~kg} \mathrm{ha}^{-1}\right)$} \\
\hline Inoculation & 0 & 45 & 90 & 135 & 180 \\
\hline Control & $24.45 \mathrm{a}$ & $21.99 \mathrm{~b}$ & $22.14 \mathrm{~b}$ & $23.85 \mathrm{~b}$ & $26.80 \mathrm{a}$ \\
\hline Azo & $25.16 \mathrm{a}$ & $30.29 a$ & $26.28 \mathrm{a}$ & $18.23 \mathrm{~b}$ & $27.10 \mathrm{a}$ \\
\hline $\mathrm{Bac}$ & $21.75 \mathrm{a}$ & $24.69 \mathrm{~b}$ & $24.69 \mathrm{~b}$ & $27.51 \mathrm{a}$ & $24.13 \mathrm{a}$ \\
\hline Pseud & $24.02 \mathrm{a}$ & $22.56 \mathrm{~b}$ & $30.84 \mathrm{a}$ & $32.19 \mathrm{a}$ & $27.50 \mathrm{a}$ \\
\hline $\mathrm{Azo}+\mathrm{Bac}$ & $27.25 \mathrm{a}$ & $30.33 \mathrm{a}$ & $21.17 \mathrm{~b}$ & $26.35 \mathrm{a}$ & $25.87 \mathrm{a}$ \\
\hline Azo + Pseud & $25.08 \mathrm{a}$ & $26.27 \mathrm{~b}$ & $28.11 \mathrm{a}$ & $28.56 \mathrm{a}$ & $27.61 \mathrm{a}$ \\
\hline Bac + Pseud & $27.18 \mathrm{a}$ & $26.11 b$ & $28.07 \mathrm{a}$ & $29.93 \mathrm{a}$ & $27.57 \mathrm{a}$ \\
\hline $\mathrm{Azo}+\mathrm{Bac}+$ Pseud & $23.51 \mathrm{a}$ & $24.14 \mathrm{~b}$ & $24.98 \mathrm{~b}$ & $21.03 \mathrm{~b}$ & $24.76 \mathrm{a}$ \\
\hline Standard error & & & 1.69 & & \\
\hline
\end{tabular}

Averages followed by the same letter in the columns belong to the same group by the Scott and Knott test at $5 \%$ probability. Control (without inoculation); Azo (Azospirillum brasilense); Bac (Bacillus subtilis); Pseud (Pseudomonas fluorescens); Azo + Bac (A. brasilense + B. subtilis); Azo + Pseud (A. brasilense + P. fluorescens); Bac + Pseud (B. subtilis + P. fluorescens); Azo + Bac + Pseud (A. brasilense + B. subtilis + P. fluorescens $).$

\section{Discussion}

Our results indicated that PGPB inoculation favored $\mathrm{P}$ absorption as verified by increased leaf $P$ concentration with $P$. fluorescens inoculation (an increase of $7.1 \%$ ), A. brasilense + B. subtilis (an increase of 5.3\%), B. subtilis + P. fluorescens (an increase of $10.2 \%$ ) and A. brasilense $+B$. subtilis $+P$. fluorescens (an increase of $4.4 \%$ ), respectively. Although leaf $\mathrm{N}$ concentration was not greatly influenced by inoculations, the same above-mentioned treatments provided a numerical increase on $\mathrm{N}$ concentration varying between $2.6 \%$ to $5.7 \%$. The $\mathrm{N}$ concentration (varying between 19.5 and $21.1 \mathrm{~g} \mathrm{~N} \mathrm{~kg}^{-1}$ ) and $\mathrm{P}$ concentration in sugarcane leaf tissue (varying between 2.2 and $2.5 \mathrm{~g} \mathrm{P} \mathrm{kg}^{-1}$ ) were in the suitable concentration range for $\mathrm{N}$ (18-25 g kg-1 D.M.) and $\mathrm{P}\left(1.5-3.0 \mathrm{~g} \mathrm{~kg}^{-1}\right.$ of D.M.) according to van 
Raij [11]. Phosphorus serves as an energy booster for the activation of certain endergonic activities including, nutrients assimilation, organic compounds production $[40,41]$, and also root-shoot growth of the plants [42,43]. Phosphorus has several benefits in tropical sugarcane crops [44,45], decreasing unavailable soil $\mathrm{P}$ content by increasing its availability to sugarcane plants under low P fertilizer rates [16]. Several PGPB can increase plant $P$ availability through phosphate solubilization by adapting mechanisms such as acidification, chelation, organic acid production, secreting acid phosphatase that mineralizes organic-P [46]. In addition, some PGPBs can mineralize organic sources of P through the action of phytases, as well as acid and alkaline phosphatases [47,48]. They can also prevent $\mathrm{P}$ adsorption under conditions limiting $\mathrm{P}$ nutrient by assimilating solubilized phosphate. Thus, these microorganisms can act as a reservoir and supply $\mathrm{P}$ to plants upon their demand [46]. Singh et al. [49] exhibited that effective $\mathrm{N}$-fixing bacteria more prominently increased certain physiological and growth activities of sugarcane, $\mathrm{P}$ accessibility, synthesis of indole acetic acid producers. While Beneduzi et al. [50], demonstrated that phosphate solubilizing bacteria and indole acetic acid producers in sugarcane promoted a beneficial effect on plant-bacteria interaction. Therefore, the inoculation of plants with more than one species of plant growth-promoting bacteria, combined with mineral fertilization is interesting and results in mechanisms that increase sugarcane nutrition, yield, and quality. This is anticipated to happen due to the impact of different quantitative modes of action and may ensure that at most one mode of action is explicated in a specific agro-system [51], and indeed, multi-functional strains are typically the most efficient PGPB [52].

Previous studies performed under controlled conditions already demonstrated the potential of PGPBs to improve sugarcane yields [53]. Also, the positive effect of PGPBs on plant biomass and nutrition has been observed in soils with low $\mathrm{P}$ availability [48]. Magallon-Servin et al. [54] verified an increase in N, P, and K uptake by maize plants due to the inoculation with PGPBs related to phosphate solubilization (PSBs) in a low-P soil fertilized with rock phosphate. Similarly, the co-inoculation of bean plants with Rhizobium sp. and PSBs strains increased nodule weight, shoot dry weight, and N fixation when compared with the single inoculation with Rhizobium sp. [55]. In sugarcane field experiments, the co-inoculation of $A$. brasilense and B. subtilis also contributed to reducing $P$ fertilization by $75 \%$ [12]. Lopes et al. [13] concluded that the application of sugarcane by-products enriched with phosphate rocks and PSBs (P. aeruginosa PSBR12, Bacillus sp. BACBR01, BACBR04, BACBR06, and Rhizobium sp. RIZBR01) is a great alternative to increase $\beta$-glucosidase activity and the content of labile and moderately labile $P$ fractions in tropical soils. Estrada-Bonilla et al. [48] verified that the use of compost (filter cake and ashes) and PSBs (Bacillus sp. BACBR04, Bacillus sp. BACBR06, and Rhizobium sp. RIZBR01) improved soil $\mathrm{P}$ availability and positively affected sugarcane plant nutrition mainly due to an increase in the abundance of phytate-degrading enzymes correlated with the improvement of organic labile P in soil when PSBs are co-inoculated. This evidence further supports the potential of PGPBs to increase sugarcane plant nutrition by enhancing P-fertilization even with low solubility P sources and improving soil P lability. Nonetheless, the inoculation with PGPBs probably improved the physiological attributes of the plant since inoculation with microorganisms has the potential to increase plant and root growth [18]. Increased root biomass can positively influence root scavenging, which is important for the interception of nutrients in crop systems such as $\mathrm{P}$ leading to a greater P-fertilizer use efficiency (PUE). For example, Pereira et al. [36] concluded that inoculation with $A$. brasilense and $B$. subtilis can increase $P$ uptake, benefiting productive components development, leading to an improved PUE, and greater maize grain yield. According to these authors, $\mathrm{P}$ uptake and PUE increased 100.5 and $54.6 \%$ as a result of $A$. brasilense and B. subtilis inoculation compared to non-inoculated treatments. Therefore, further investigation related to PGPBs roles, and the key mechanisms related to phosphate solubilization and PUE should be performed.

Although PGPB inoculation differently responds under $\mathrm{P}_{2} \mathrm{O}_{5}$ application rates, our results showed that combinations of PGPBs inoculation provided greater sugarcane tech- 
nological quality. We verified that response to single inoculation of $P$. fluorescens and A. brasilense $+B$. subtilis associated with low $\left(45 \mathrm{~kg} \mathrm{P}_{2} \mathrm{O}_{5} \mathrm{ha}^{-1}\right)$ and average (90 and $135 \mathrm{~kg} \mathrm{P}_{2} \mathrm{O}_{5} \mathrm{ha}^{-1}$ ) rates provided greater Brix and Pol. Also, Brix and Pol content were greater with $A$. brasilense $+B$. subtilis when associated with a high $\mathrm{P}_{2} \mathrm{O}_{5}$ rate $\left(180 \mathrm{~kg} \mathrm{ha}^{-1}\right)$. Fiber content was not greatly influenced by inoculations and $\mathrm{P}_{2} \mathrm{O}_{5}$ rates. However, when $180 \mathrm{~kg} \mathrm{P}_{2} \mathrm{O}_{5} \mathrm{ha}^{-1}$ was applied together with single inoculation of $A$. brasilense, $P$. fluorescens, and $B$. subtilis and combinations of $A$. brasilense and P. fluorescens and $A$. brasilense $+B$. subtilis and $P$. fluorescens reduced fiber content between $2.4 \%$ and $10.8 \%$. The improved Brix and Pol content, together with reduced fiber content, led to a greater TRS. In the absence of $\mathrm{P}_{2} \mathrm{O}_{5}$ fertilization, $B$. subtilis $+P$. fluorescens provided $3.8 \%$ greater TRS compared to control (non-inoculated) treatments. The low and average $\mathrm{P}_{2} \mathrm{O}_{5}$ application rates $(45,90$, and $135 \mathrm{~kg} \mathrm{P}_{2} \mathrm{O}_{5} \mathrm{ha}^{-1}$ ) together with A. brasilense $+B$. subtilis + P. fluorescens inoculation increased TRS by $6.1 \%, 4.1 \%$, and $5.4 \%$, respectively, compared to control treatments. The application of higher $\mathrm{P}_{2} \mathrm{O}_{5}$ rates $\left(180 \mathrm{~kg} \mathrm{ha}^{-1}\right)$ together with $P$. fluorescens inoculation provided an increase of $7.1 \%$ in TRS, compared to control treatment.

Sugarcane yield was also benefited with PGPB inoculation and $\mathrm{P}_{2} \mathrm{O}_{5}$ rates. Stalk and sugar yield showed greater production with inoculation of $A$. brasilense and $A$. brasilense $+B$. subtilis when associated with $45 \mathrm{~kg} \mathrm{P}_{2} \mathrm{O}_{5} \mathrm{ha}^{-1}$. The application of $90 \mathrm{~kg} \mathrm{P}_{2} \mathrm{O}_{5} \mathrm{ha}^{-1}$ along with single inoculation of $A$. brasilense and $P$. fluorescens and combined inoculation of $A$. brasilense $+P$. fluorescens and B. subtilis $+P$. fluorescens provided greater STY and SUY. Similarly, application of $135 \mathrm{~kg} \mathrm{P}_{2} \mathrm{O}_{5} \mathrm{ha}^{-1}$ in association with single inoculation of B. subtilis and P. fluorescens and combined inoculation of $A$. brasilense $+B$. subtilis, A. brasilense $+P$. fluorescens, and B. subtilis $+P$. fluorescens provided greater STY and SUY. Our results showed that the application of $\mathrm{P}_{2} \mathrm{O}_{5}$ at the rate of $180 \mathrm{~kg} \mathrm{ha}^{-1}$ without inoculation provided greater STY and SUY. However, inoculations with A. brasilense + B. subtilis increased stalk yield with a reduction of $75 \%$ in $\mathrm{P}_{2} \mathrm{O}_{5}$ application rates (180 to $\left.45 \mathrm{~kg} \mathrm{P}_{2} \mathrm{O}_{5} \mathrm{ha}^{-1}\right)$. We verified an increase of $8.4 \%$ in stalk yield with inoculation of A. brasilense + B. subtilis under the treatment of $45 \mathrm{~kg} \mathrm{P}_{2} \mathrm{O}_{5} \mathrm{ha}^{-1}$ when compared to the application of $180 \mathrm{~kg} \mathrm{P}_{2} \mathrm{O}_{5} \mathrm{ha}^{-1}$ without inoculation. In addition, $A$. brasilense $+B$. subtilis inoculation and $45 \mathrm{~kg} \mathrm{P}_{2} \mathrm{O}_{5} \mathrm{ha}^{-1}$ provided an increase of $13.2 \%$ in sugarcane yield compared to the application of $180 \mathrm{~kg} \mathrm{P}_{2} \mathrm{O}_{5} \mathrm{ha}^{-1}$ without inoculation.

The exact mechanisms underlying the effect of $A$. brasilense and B. subtilis on sugarcane yield and quality were not evaluated in the present study. However, the current field trail verified that increased $\mathrm{P}$ availability and uptake along with the inoculation of $A$. brasilense and B. subtilis were prominently observed in the form of high leaf $\mathrm{P}$ content, growth, industrial quality, and yield of sugarcane crops [56-60]. The gene sequence of $A$. brasilense (strains Ab-V5 and Ab-V6) highlighted its role in auxins synthesis [29], increased availability of nutrients [61], and BNF [62,63]. In addition, B. subtilis is described with the potential ability to promote plant growth, P solubilization, and inhibit infestation of phytopathogenic attack and heavy metal accumulation [64-66]. Bacillus sp. is a genus that is characterized for being an excellent phosphate solubilizer, including the species of $B$. subtilis which becomes essential under the consideration that $\mathrm{P}$ is one of the most critical nutrients to increase crop yields $[67,68]$. The studies exhibited that under the inoculation of A. brasilense and $B$. subtilis, plants may adapt different mechanisms to more potentially scrutinize and uptake soil P $[58,66,68]$.

The single inoculation with $P$. fluorescens and/or in combination with A. brasilense and $B$. subtilis also benefited leaf $\mathrm{P}$ concentration, industrial quality, and yield of sugarcane. Pseudomonas fluorescens is presently considered the most efficient bacteria, using secondary metabolites as a bio-control agent with the synthesis of antibiotics, volatile organic compounds to combat soil pathogens $[69,70]$, promising phosphate solubilization [71] and $\mathrm{N}$ fixation activities [72]. According to Pineda [73], luconic acid is among the different types of organic acids involved in phosphate solubilization which is produced by Pseudomonas sp. Thus, new studies assessing multiple effects of different PGPB applied in combination 
should be performed to improve $\mathrm{P}_{2} \mathrm{O}_{5}$-based fertilizers application aiming at improved sustainable sugarcane production systems.

\section{Conclusions}

Inoculation with Bacillus subtilis + Pseudomonas fluorescens provided the highest leaf concentration of $P$ in the diagnostic leaf of plant-cane, RB92579 variety.

The combination of Azospirillum brasilense with the application of $45 \mathrm{~kg} \mathrm{P}_{2} \mathrm{O}_{5} \mathrm{ha}^{-1}$ promoted the best agro-industrial quality of sugarcane.

In the absence of phosphate fertilizer and the highest rate of $\mathrm{P}_{2} \mathrm{O}_{5}\left(180 \mathrm{~kg} \mathrm{ha}^{-1}\right)$, stalk yield (STY) and sugar yield (SUY) were not positively influenced by inoculation with PGPBs, alone or in combination, demonstrating that extremes were detrimental to obtain satisfactory results.

Inoculation with Azospirillum brasilense + Bacillus subtilis associated with $45 \mathrm{~kg} \mathrm{P}_{2} \mathrm{O}_{5} \mathrm{ha}^{-1}$ at planting is recommended, as this treatment increases the yield of sugarcane stalks by $38 \%$ when compared to the control treatment (without inoculation), at the same rate, in soil with low $\mathrm{P}$ content. This treatment also increases sugar yield, resulting in a savings of $75 \%$ of the recommended $\mathrm{P}_{2} \mathrm{O}_{5}$ rate, thus being a more efficient and sustainable alternative for reducing sugarcane crop production costs.

Author Contributions: Conceptualization: P.A.L.R., M.C.M.T.F; Methodology: P.A.L.R., F.S.G., A.J., E.S.M., G.C.F., E.M.R.M.; Investigation: P.A.L.R., F.S.G., A.J., E.S.M., G.C.F., E.M.R.M.; Writing—Original draft: P.A.L.R., F.S.G., A.J., E.S.M.; Writing—Review and editing: F.S.G., C.E.d.S.O., S.B., M.C.M.T.F.; Supervision: S.B., M.C.M.T.F. All authors have read and agreed to the published version of the manuscript.

Funding: This research was funded by CNPq (Conselho Nacional de Desenvolvimento Científico e Tecnológico) by productivity grants in research (award numbers 305.299/2014-0 and 312359/2017-9) and the CAPES by first author's scholarship.

Data Availability Statement: All data generated or analyzed during this study are included in this published article.

Conflicts of Interest: The authors declare no conflict of interest.

\section{Appendix A}
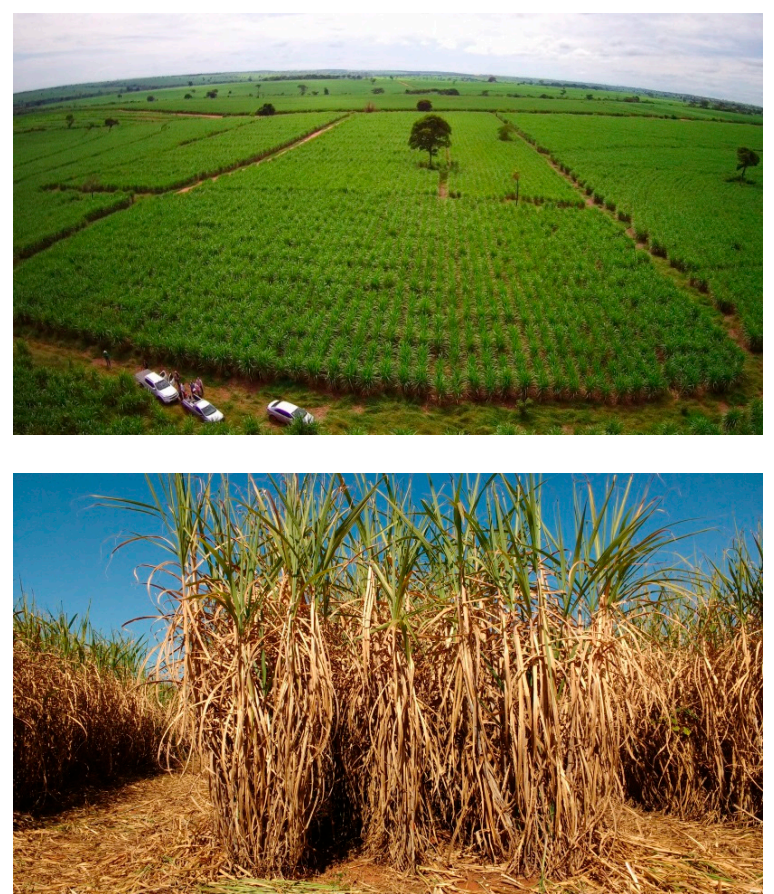

Figure A1. Cont. 

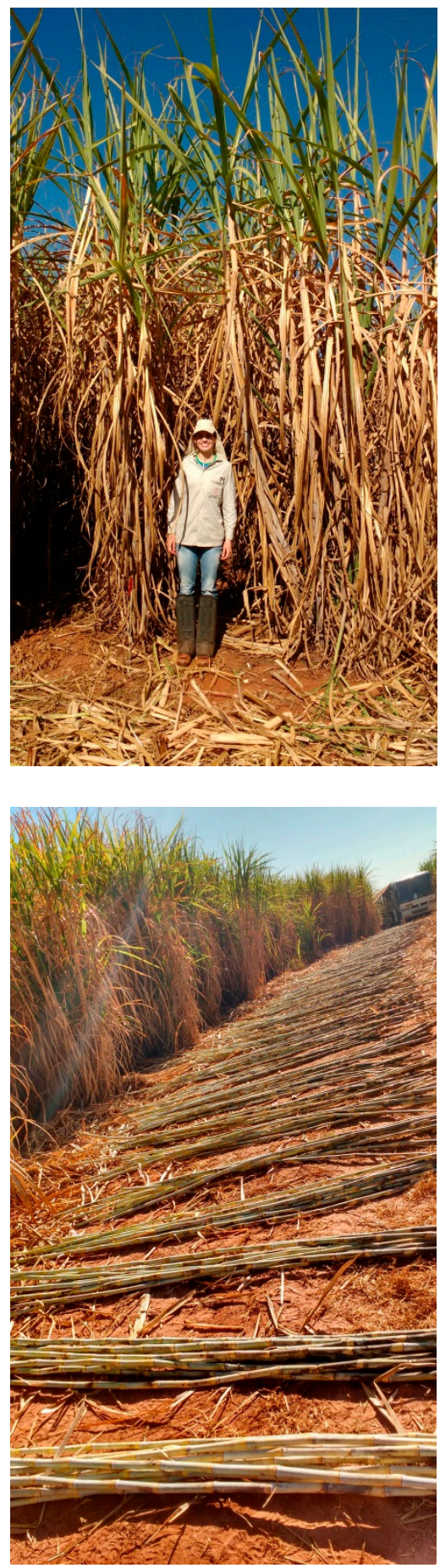

Figure A1. Photos of the experimental area with sugarcane plant samples for technological quality. Suzanapólis-SP, Brazil.

\section{References}

1. National Supply Company (CONAB). Brazilian Crop Monitoring: Sugarcane, Third Survey: 2019/20 Crop. 2019. Available online: https: / / www.conab.gov.br/ (accessed on 8 December 2021). (In Portuguese)

2. Food and Agriculture Organization of the United Nations (FAO). FAOSTAT. 2019. Available online: https://www.fao.org/ faostat/en/ (accessed on 22 December 2019).

3. Lopes, M.L.; Paulillo, S.C.L.; Godoy, A.; Cherubin, R.A.; Lorenzi, M.S.; Giometti, F.H.C.; Bernardino, C.D.; de Amorim Neto, H.B.; de Amorim, H.V. Ethanol production in Brazil: A bridge between science and industry. Braz. J. Microbiol. 2016, 47, 64-76. [CrossRef]

4. Moore, P.H.; Paterson, A.H.; Tew, T. Sugarcane: The crop, the plant, and domestication. In Sugarcane: Physiology, Biochemistry, and Functional Biology; Moore, P.H., Botha, F.C., Eds.; John Wiley \& Sons: Ames, IA, USA, 2014; pp. 1-7. 
5. Bento, C.B.; Filoso, S.; Pitombo, L.M.; Cantarella, H.; Rossetto, R.; Martinelli, L.A.; do Carmo, J.B. Impacts of sugarcane agriculture expansion over low-intensity cattle ranch pasture in Brazil on greenhouse gases. J. Environ. Manag. 2018, 206, 980-988. [CrossRef] [PubMed]

6. Penn, C.J.; Camberato, J.J. A Critical review on soil chemical processes that control how soil $\mathrm{pH}$ affects phosphorus availability to plants. Agriculture 2019, 9, 120. [CrossRef]

7. Dhillon, J.; Torres, G.; Driver, E.; Figueiredo, B.; Raun, W.R. World phosphorus use efficiency in cereal crops. Agron. J. 2017, 109, 1670-1677. [CrossRef]

8. $\quad$ Kingston, G. Mineral Nutrition of Sugarcane; Willey: New York, NY, USA, 2014.

9. Caione, G.; Prado, R.M.; Campos, C.N.S.; Moda, L.R.; Vasconcelos, R.L.; Pizauro Júnior, J.M. Response of sugarcane in a Red Ultisol to phosphorus rates, phosphorus sources, and filter cake. Sci. World J. 2015, 2015, 14-16. [CrossRef] [PubMed]

10. Costa, D.B.; Andrade, P.K.B.; Silva, S.A.M.; Simões Neto, D.E.; Freire, F.J.; Oliveira, E.C.A. P fertilization on plant and ratoon cane in the argisoils of the northeast of different textures. Rev. Caatinga 2014, 27, 47-56. (In Portuguese, abstract in English)

11. Van Raij, B.; Cantarella, H. Other industrial crops: Sugarcane. In Liming and Fertilization Recommendations for the State of São Paulo; Boletim Técnico 100; Van Raij, B., Cantarella, H., Quaggio, J.A., Furlani, A.M.C., Eds.; Instituto Agronômico de Campinas: Campinas, Brazil, 1997; 285p. (In Portuguese)

12. Rosa, P.A.L.; Mortinho, E.S.; Jalal, A.; Galindo, F.S.; Buzetti, S.; Fernandes, G.C.; Barco Neto, M.; Pavinato, P.S.; Teixeira Filho, M.C.M. Inoculation with growth-promoting bacteria associated with the reduction of phosphate fertilization in sugarcane. Front. Environ. Sci. 2020, 8, 32. [CrossRef]

13. Lopes, C.M.; Silva, A.M.M.; Estrada-Bonilla, G.A.; Ferraz-Almeida, R.; Vieira, J.L.V.; Otto, R.; Vitti, G.C.; Cardoso, E.J.B.N. Improving the fertilizer value of sugarcane wastes through phosphate rock amendment and phosphate-solubilizing bacteria inoculation. J. Clean. Prod. 2021, 298, 126821. [CrossRef]

14. Vitti, G.C.; Otto, R.; Ferreira, L.R.P. Sugarcane nutrition and fertilization. In Agricultural Processes and Mechanization of Sugarcane; Belardo, G.C., Cassia, M.T., Silva, R.P., Eds.; Associação Brasileira de Engenharia Agrícola: Jaboticabal, Brazil, 2015; pp. 177-205. (In Portuguese)

15. Zavaschi, E.; de Abreu Faria, L.; Ferraz-Almeida, R.; do Nascimento, C.A.C.; Pavinato, P.S.; Otto, R.; Vitti, A.C.; Vitti, G.C Dynamic of P flux in tropical acid soils fertilized with humic acid-complexed phosphate. J. Soil Sci. Plant Nutr. 2020, 20, 1937-1948. [CrossRef]

16. Withers, P.J.A.; Rodrigues, M.; Soltangheisi, A.; de Carvalho, T.S.; Guilherme, L.R.G.; Benites, V.D.M.; Gatiboni, L.C.; de Sousa, D.M.G.; Nunes, R.D.S.; Rosolem, C.A.; et al. Transitions to sustainable management of phosphorus in Brazilian agriculture. Sci. Rep. 2018, 8, 2537. [CrossRef]

17. Sharpley, A. Managing agricultural phosphorus to minimize water quality impacts. Sci. Agric. 2016, 73, 1-8. [CrossRef]

18. Schütz, L.; Gattinger, A.; Meier, M.; Müller, A.; Boller, T.; Mäder, P.; Mathimaran, N. Improving crop yield and nutrient use efficiency via biofertilization-A global meta-analysis. Front. Plant Sci. 2018, 8, 2204. [CrossRef] [PubMed]

19. Kuhad, R.C.; Singh, S.; Lata, A.S. Phosphate solubilizing microorganisms. In Bioaugmentation, Biostimulation and Biocontrol; Soil Biology Series 28; Singh, A., Parmar, N., Kuhad, R.C., Eds.; Springer: Berlin, Germany, 2011; pp. 65-84.

20. Mumtaz, M.Z.; Ahmad, M.; Jamil, M.; Hussain, T. Zinc solubilizing Bacillus spp. potential candidates for biofortification in maize Microbiol. Res. 2017, 202, 51-60. [CrossRef]

21. Oliveira, R.P.; Schultz, N.; Monteiro, R.C.; Pereira, W.; Araújo, A.P.; Urquiaga, S.; Reis, V.M. Growth analysis of sugarcane inoculated with diazotrophic bacteria and nitrogen fertilization. Afr. J. Agric. Res. 2016, 11, 2786-2795.

22. Patel, J.K.; Archana, G. Diverse culturable diazotrophic endophytic bacteria from Poaceae plants show cross-colonization and plant growth promotion in wheat. Plant Soil 2017, 417, 99-116. [CrossRef]

23. Hungria, M.; Ribeiro, R.A.; Nogueira, M.A. Draft genome sequences of Azospirillum brasilense strains Ab-V5 and Ab-V6, commercially used in inoculants for grasses and legumes in Brazil. Genome Announc. 2018, 6, e00393-18. [CrossRef]

24. Silva, E.R.; Zoz, J.; Oliveira, C.E.S.; Zuffo, A.M.; Steiner, F.; Zoz, T.; Vendruscolo, E.P. Can co-inoculation of Bradyrhizobium and Azospirillum alleviate adverse effects of drought stress on soybean (Glycine max L. Merrill.)? Arch. Microbiol. 2019, 201, 325-335. [CrossRef] [PubMed]

25. Galindo, F.S.; Buzetti, S.; Rodrigues, W.L.; Boleta, E.H.M.; Silva, V.M.; Tavanti, R.F.R.; Fernandes, G.C.; Biagini, A.L.C.; Rosa, P.A.L.; Teixeira Filho, M.C.M. Inoculation of Azospirillum brasilense associated with silicon as a liming source to improve nitrogen fertilization in wheat crops. Sci. Rep. 2020, 10, 6160. [CrossRef]

26. Steiner, F.; Oliveira, C.E.S.; Zoz, T.; Zuffo, A.M.; de Freitas, R.S. Co-Inoculation of common bean with Rhizobium and Azospirillum enhance the drought tolerance. Russ. J. Plant Physiol. 2020, 67, 923-932. [CrossRef]

27. Tayade, A.S.; Geetha, P.; Anusha, S.; Dhanapal, R.; Hari, K. Bio-intensive modulation of sugarcane ratoon rhizosphere for enhanced soil health and sugarcane productivity under tropical Indian condition. Sugar Tech 2019, 21, 278-288. [CrossRef]

28. Barreto, M.C.S.; Figueiredo, M.V.B.; Silva, M.V.; Oliveira, J.P.; Andrade, A.G.; Almeida, C.M.A.; Ferreira Junior, M.U.; Santos, C.E.R.S.; Reis Junior, O.V.; Lima, V.L.M. Inoculation of endophlytic diazotrophic bacteria in micro propagated seedlings of sugarcane (Saccharum officinarum sp.). Environ. Sustain. 2019, 2, 5-12. [CrossRef]

29. Marra, L.M.; de Oliveira, S.M.; Soares, C.R.F.S.; Moreira, F.M.S. Solubilisation of inorganic phosphates by inoculant strains from tropical legumes. Sci. Agric. 2011, 68, 603-609. [CrossRef] 
30. Bashan, Y.; Holguin, G.; de-Bashan, L.E. Azospirillum-plant relationships: Physiological, molecular, agricultural, and environmental advances (1997-2003). Can. J. Microbiol. 2004, 50, 521-577. [CrossRef]

31. Florio, A.; Pommier, T.; Gervaix, J.; Bérard, A.; Le Roux, X. Soil C and N statuses determine the effect of maize inoculation by plant growth promoting rhizobacteria on nitrifying and denitrifying communities. Sci. Rep. 2017, 7, 8411. [CrossRef] [PubMed]

32. Embrapa. Brazilian Soil Classification System, 5th ed.; Embrapa: Brasília, Brazil, 2018. (In Portuguese)

33. Soil Survey Staff. Keys to Soil Taxonomy-USDA; Natural Resources Conservation Service: Washington, DC, USA, 2014.

34. Embrapa. Manual of Soil Analysis Methods; Centro Nacional de Pesquisa de Solos: Rio de Janeiro, Brazil, 2017; p. 575. (In Portuguese)

35. Oliveira, L.B.G.; Teixeira Filho, M.C.M.; Galindo, F.S.; Nogueira, T.A.R.; Barco Neto, M.; Buzetti, S. Forms and types of coinoculation in the soybean crop in Cerrado region. Rev. Cienc. Agrar. 2019, 42, 924-932. (In Portuguese, Abstract in English)

36. Pereira, N.C.M.; Galindo, F.S.; Gazola, R.P.D.; Dupas, E.; Rosa, P.A.L.; Mortinho, E.S.; Teixeira Filho, M.C.M. Corn yield and phosphorus use efficiency response to phosphorus rates associated with plant growth promoting bacteria. Front. Environ. Sci. 2020, 8, 40. [CrossRef]

37. Malavolta, E.; Vitti, G.C.; Oliveira, S.A. Evaluation of Plant Nutritional Status: Principles and Applications; Potafos: Piracicaba, Brazil, 1997. (In Portuguese)

38. Fernandes, A.C. Calculations in the Sugarcane Agribusiness; STAB: Piracicaba, Brazil, 2011. (In Portuguese)

39. R Development Core Team. A Language and Environment for Statistical Computing; R Foundation for Statistical Computing: Vienna, Austria, 2015. Available online: http:/ / www.R-project.org/ (accessed on 16 December 2021).

40. Marschner, P. Marschner's Mineral Nutrition of Higher Plants, 3rd ed.; Academic Press: New York, NY, USA, 2012.

41. Lollato, R.P.; Figueiredo, B.M.; Dhillon, J.S.; Arnall, D.B.; Raun, W.R. Wheat grain yield and grain-nitrogen relationships as affected by N, P, and K fertilization: A synthesis of long-term experiments. Field Crops Res. 2019, 236, 42-57. [CrossRef]

42. Zhang, Y.; Thomas, C.L.; Xiang, J.; Long, Y.; Wang, X.; Zou, J.; Luo, Z.; Ding, G.; Cai, H.; Graham, N.S.; et al. QTL meta-analysis of root traits in Brassica napus under contrasting phosphorus supply in two growth systems. Sci. Rep. 2016, 6, 33113. [CrossRef]

43. Galindo, F.S.; Strock, J.S.; Pagliari, P.H. Nutrient accumulation affected by corn stover management associated with nitrogen and phosphorus fertilization. Agriculture 2021, 11, 1118. [CrossRef]

44. Soltangheisi, A.; Withers, P.J.A.; Pavinato, P.S.; Cherubin, M.R.; Rossetto, R.; Do Carmo, J.B.; da Rocha, G.C.; Martinelli, L.A. Improving phosphorus sustainability of sugarcane production in Brazil. GCB Bioenergy 2019, 11, 1444-1455. [CrossRef]

45. Pavinato, P.S.; Cherubin, M.R.; Soltangheisi, A.; Rocha, G.C.; Chadwick, D.R.; Jones, D.L. Revealing soil legacy phosphorus to promote sustainable agriculture in Brazil. Sci. Rep. 2020, 10, 15615. [CrossRef] [PubMed]

46. Afzal, I.; Shinwari, Z.K.; Sikandar, S.; Shahzad, S. Plant beneficial endophytic bacteria: Mechanisms, diversity, host range and genetic determinants. Microbiol. Res. 2019, 221, 36-49. [CrossRef]

47. Khan, M.S.; Zaidi, A.; Ahmad, E. Mechanism of phosphate solubilization and physiological functions of phosphate-solubilizing microorganisms. In Phosphate Solubilizing Microorganisms: Principles and Application of Microphos Technology; Khan, M.S., Zaidi, A., Musarrat, J., Eds.; Springer International Publishing: Cham, Switzerland, 2014; pp. 31-62.

48. Estrada-Bonilla, G.A.; Durrer, A.; Cardoso, E.J.B.N. Use of compost and phosphate-solubilizing bacteria affect sugarcane mineral nutrition, phosphorus availability, and the soil bacterial community. Appl. Soil Ecol. 2021, 157, 103760. [CrossRef]

49. Singh, P.; Singh, R.K.; Li, H.B.; Guo, D.J.; Sharma, A.; Lakshmanan, P.; Malviya, M.K.; Song, X.P.; Solanki, M.K.; Verma, K.K.; et al. Diazotrophic bacteria Pantoea dispersa and Enterobacter asburiae promote sugarcane growth by inducing nitrogen uptake and defense-related gene expression. Front. Microbiol. 2021, 11, 3272. [CrossRef]

50. Beneduzi, A.; Moreira, F.; Costa, P.B.; Vargas, L.K.; Lisboa, B.B.; Favreto, R.; Baldani, J.I.; Passaglia, L.M.P. Diversity and plant growth promoting evaluation abilities of bacteria isolated from sugarcane cultivated in the South of Brazil. Appl. Soil Ecol. 2013, 63, 94-104. [CrossRef]

51. Vacheron, J.; Moënne-Loccoz, Y.; Dubost, A.; Gonçalves-Martins, M.; Muller, D.; Prigent-Combaret, C. Pseudomonas fluorescens strains with only few plant-beneficial properties are favored in the maize rhizosphere. Front. Plant Sci. 2016, 7, 1212. [CrossRef]

52. Almario, J.; Muller, D.; Défago, G.; Moënne-Loccoz, Y. Minireview: Rhizosphere ecology and phytoprotection in soils naturally suppressive to Thielaviopsis black root rot of tobacco. Environ. Microbiol. 2014, 16, 1949-1960. [CrossRef]

53. Arruda, B.; Rodrigues, M.; Gumiere, T.; Richardson, A.E.; Andreote, F.D.; Soltangheisi, A.; Gatiboni, L.C.; Pavinato, P.S. The impact of sugarcane filter cake on the availability of $\mathrm{P}$ in the rhizosphere and associated microbial community structure. Soil Use Manag. 2019, 35, 334-345. [CrossRef]

54. Magallon-Servin, P.; Antoun, H.; Taktek, S.; de-Bashan, L.E. Designing a multi-species inoculant of phosphate rock-solubilizing bacteria compatible with arbuscular mycorrhizae for plant growth promotion in low-P soil amended with PR. Biol. Fertil. Soils 2020, 56, 521-536. [CrossRef]

55. Korir, H.; Mungai, N.W.; Thuita, M.; Hamba, Y.; Masso, C. Co-inoculation effect of Rhizobia and plant growth promoting rhizobacteria on common bean growth in a low phosphorus soil. Front. Plant Sci. 2017, 8, 141. [CrossRef]

56. Fukami, J.; Ollero, F.J.; Megías, M.; Hungria, M. Phytohormones and induction of plant-stress tolerance and defense genes by seed and foliar inoculation with Azospirillum brasilense cells and metabolites promote maize growth. AMB Express 2017, 7, 153. [CrossRef] 
57. Jang, J.H.; Kim, S.H.; Khaine, I.; Kwak, M.J.; Lee, H.K.; Lee, T.Y.; Lee, W.Y.; Woo, S.Y. Physiological changes and growth promotion induced in poplar seedlings by the plant growth-promoting rhizobacteria Bacillus subtilis JS. Photosynthetica 2018, 56, 1188-1203. [CrossRef]

58. Martins, M.R.; Jantalia, C.P.; Reis, V.M.; Döwich, I.; Polidoro, J.C.; Alves, B.J.R.; Boddey, R.M.; Urquiaga, S. Impact of plant growth-promoting bacteria on grain yield, protein content, and urea- ${ }^{15} \mathrm{~N}$ recovery by maize in a Cerrado Oxisol. Plant Soil 2018, 422, 239-250. [CrossRef]

59. Posada, L.F.; Álvarez, J.C.; Romero-Tabarez, M.; de-Bashan, L.; Villegas-Escobar, V. Enhanced molecular visualization of root colonization and growth promotion by Bacillus subtilis EA-CB0575 in different growth systems. Microbiol. Res. 2018, 217, 69-80. [CrossRef] [PubMed]

60. Di Salvo, L.P.; Ferrando, L.; Fernández-Scavino, A.; García de Salamone, I.E. Microorganisms reveal what plants do not: Wheat growth and rhizosphere microbial communities after Azospirillum brasilense inoculation and nitrogen fertilization under field conditions. Plant Soil 2018, 424, 405-417. [CrossRef]

61. Galindo, F.S.; Teixeira Filho, M.C.M.; Buzetti, S.; Pagliari, P.H.; Santini, J.M.K.; Alves, C.J.; Megda, M.M.; Nogueira, T.A.R.; Andreotti, M.; Arf, O. Maize yield response to nitrogen rates and sources associated with Azospirillum brasilense. Agron. J. 2019, 111, 1985-1997. [CrossRef]

62. Pankievicz, V.C.S.; do Amaral, F.P.; Santos, K.F.D.N.; Agtuca, B.; Xu, Y.; Schueller, M.J.; Arisi, A.M.C.; Steffens, M.B.; de Souza, E.M.; Pedrosa, F.O.; et al. Robust biological nitrogen fixation in a model grass-bacterial association. Plant J. 2015, 81, 907-919. [CrossRef] [PubMed]

63. Skonieski, F.R.; Viégas, J.; Martin, T.N.; Carlos, C.; Mingotti, A.; Naetzold, S.; Tonin, T.J.; Dotto, L.R.; Meinerz, G.R. Effect of nitrogen topdressing fertilization and inoculation of seeds with Azospirillum brasilense on corn yield and agronomic characteristics. Agronomy 2019, 9, 812. [CrossRef]

64. Rekha, K.; Baskar, B.; Srinath, S.; Usha, B. Plant-growth-promoting rhizobacteria Bacillus subtilis RR4 isolated from rice rhizosphere induces malic acid biosynthesis in rice roots. Can. J. Microbiol. 2018, 64, 20-27. [CrossRef] [PubMed]

65. Muñoz-Moreno, C.Y.; La Cruz-Rodríguez, Y.D.; Vega-Arreguín, J.; Alvarado-Rodríguez, M.; Gómez-Soto, J.M.; Alvarado-Gutiérrez, A.; Fraire-Velázquez, S. Draft genome sequence of Bacillus subtilis 2C-9B, a strain with biocontrol potential against chili pepper root pathogens and tolerance to $\mathrm{Pb}$ and $\mathrm{Zn}$. Genome Announc. 2018, 6, 2-3. [CrossRef]

66. Prakash, J.; Arora, N.K. Phosphate-solubilizing Bacillus sp. enhances growth, phosphorus uptake and oil yield of Mentha arvensis L. 3 Biotech 2019, 9, 126. [CrossRef] [PubMed]

67. Ramírez, L.C.C.; Leal, L.C.S.; Galvez, Y.A.; Burbano, V.E.M. Bacillus: A genus of bacteria that exhibits important phosphate solubilizing abilities. Nova 2014, 12, 165-178. (In Spanish)

68. Zeffa, D.I.M.; Perini Júnior, L.; Silva, M.B.; Sousa, N.V.; Scapim, C.A.; Oliveira, A.L.M.; Amaral Júnior, A.T.; Gonçalves, L.S.A Azospirillum brasilense promotes increases in growth and nitrogen use efficiency of maize genotypes. PLoS ONE 2019, 14, e0215332. [CrossRef] [PubMed]

69. David, B.V.; Chandrasehar, G.; Selvam, P.N. Pseudomonas fluorescens: A plant-growth-promoting rhizobacterium (PGPR) with potential role in biocontrol of pests of crops. In Crop Improvement through Microbial Biotechnology; Elsevier: Amsterdam, The Netherlands, 2018; pp. 221-243.

70. Kamble, R.; Jadhav, P.; Gurjar, M. Biocontrol potential of Pseudomonas species against phytopathogens. Int. Res. J. Mod. Eng. Technol. Sci. 2020, 2, 558-568.

71. Alaylar, B.; Egamberdieva, D.; Gulluce, M.; Karadayi, M.; Arora, N.K. Integration of molecular tools in microbial phosphate solubilization research in agriculture perspective. World J. Microbiol. Biotechnol. 2020, 36, 93. [CrossRef]

72. Jing, X.; Cui, Q.; Li, X.; Yin, J.; Ravichandran, V.; Pan, D.; Fu, J.; Tu, Q.; Wang, H.; Bian, X.; et al. Engineering Pseudomonas protegens Pf-5 to improve its antifungal activity and nitrogen fixation. Microb. Biotechnol. 2020, 13, 118-133. [CrossRef]

73. Pineda, M.E.B. Phosphate solubilization as a microbial strategy for promoting plant growth. Corpoica Cienc. Tecnol. Agropecu. 2014, 15, 101-113. (In Spanish, abstract in English) 